\title{
Effects of long-term flooding on biogeochemistry and vegetation development in floodplains; a mesocosm experiment to study interacting effects of land use and water quality
}

\author{
A. M. Banach ${ }^{1,2}$, K. Banach ${ }^{1,3}$, R. C. J. H. Peters ${ }^{2}$, R. H. M. Jansen ${ }^{2}$, E. J. W. Visser ${ }^{3}$, Z. Stępniewska ${ }^{1}$, \\ J. G. M. Roelofs ${ }^{2}$, and L. P. M. Lamers ${ }^{2}$ \\ ${ }^{1}$ The John Paul II Catholic University of Lublin, Dept. of Biochemistry and Environmental Chemistry, Kraśnicka 102, \\ 20-718, Lublin, Poland \\ ${ }^{2}$ Radboud University Nijmegen, Dept. of Aquatic Ecology and Environmental Biology, Institute for Water and Wetland \\ Research, Toernooiveld 1, 6525 ED Nijmegen, the Netherlands \\ ${ }^{3}$ Radboud University Nijmegen, Dept. of Experimental Plant Ecology, Institute for Water and Wetland Research, \\ Toernooiveld 1, 6525 ED Nijmegen, the Netherlands
}

Received: 25 February 2009 - Published in Biogeosciences Discuss.: 26 March 2009

Revised: 23 June 2009 - Accepted: 29 June 2009 - Published: 30 July 2009

\begin{abstract}
Raising safety levees and reinforcing dykes is not a sufficient and sustainable solution to the intense winter and summer floods occurring with increasing frequency in Eastern Europe. An alternative, creating permanently flooded floodplain wetlands, requires improved understanding of ecological consequences. A 9 month mesocosm study (starting in January), under natural light and temperature conditions, was initiated to understand the role of previous land use (fertility intensity) and flooding water quality on soil biogeochemistry and vegetation development. Flooding resulted in severe eutrophication of both sediment pore water and surface water, particularly for more fertilized soil and sulphate pollution. Vegetation development was mainly determined by soil quality, resulting in a strong decline of most species from the highly fertilized location, especially in combination with higher nitrate and sulphate concentrations. Soils from the less fertilized location showed, in contrast, luxurious growth of target Carex species regardless water quality. The observed interacting effects of water quality and agricultural use are important in assessing the consequences of planned measures for ecosystem functioning and biodiversity in river floodplains.
\end{abstract}

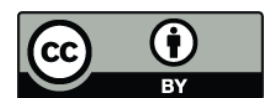

Correspondence to: L. P. M. Lamers (1.lamers@science.ru.nl)

\section{Introduction}

In riverine regions in Eastern Europe, both the frequency and the severity of flooding have increased in the last decades (Bronstert, 2003), not only in regulated rivers systems but also in more pristine rivers such as the Vistula and Odra in Poland (Kundzewicz et al., 2005). In addition, it is expected that the intensity and frequency of both winter and summer flood events will increase in the future probably due to global climate change (Milly et al., 2002; Christensen and Christensen, 2003; Kundzewicz et al., 2005; Beniston et al., 2007).

Because flood prevention by raising dykes seems to be insufficient in the future, new strategies have been proposed which allow creating more space for floodwater by dyke/levee displacement and creation of wetlands and secondary channels. These aim to combine several goals including safety, the restoration of other floodplain functions (land accretion, recreation, water storage), and nature restoration of both riparian wetlands and permanently flooded marshes (Smits et al., 2000; van Stokkom et al., 2005). It is, however, difficult to optimally combine all goals, and restoration projects often result in low biodiversity as a result of eutrophication (Antheunisse et al., 2006; Lamers et al., 2006). In addition, it is a problem to restore peat forming vegetation (e.g. Carex species) in marshes, which is important to counteract the effects of land subsidence (mechanical compression and oxidation) resulting from agricultural drainage and eutrophication (Wösten et al., 1997; Schipper and McLeod, 2002), although this will decrease the hydrological retention capacity.

Published by Copernicus Publications on behalf of the European Geosciences Union. 
The development of vegetation in floodplains is strongly determined by flooding characteristics (Vervuren et al., 2003; van Eck et al., 2004, 2005) and flooding tolerance of vegetation (Blom et al., 1990; van Eck et al., 2004). Oxygen deprivation, light limitation and reduced $\mathrm{CO}_{2}$ availability restrict the metabolic efficiency (Mommer et al., 2005; Banach et al., 2009a) and therefore lead to biomass reduction (Pezeshki, 2001; van Eck et al., 2004). Wetland species have developed a number of adaptations (Mommer and Visser, 2005; Banach et al., 2009a) to cope with these stress factors including the ability to oxidize the rhizosphere (Pezeshki, 2001; Colmer, 2003).

Next, the changed biogeochemistry as affected by the combined effects of changes in water quality, soil quality and hydrological regime may also form a constraint for successful rehabilitation of riverine wetlands. The microbially governed processes in soil strongly depend on the soil aeration state, and after inundation oxygen is depleted resulting in the mobilization of reduced (often toxic) substances such as nitrite, ammonium and sulphide. As a result of iron reduction, phosphate is mobilized during flooding (Gliński and Stępniewski, 1985; Laanbroek, 1990; Smolders et al., 2006; Banach et al., 2009b).

For the creation of marshes, both the composition of the flood water and soil characteristics may strongly interact with the biogeochemical effects of flooding (Swarzenski et al., 2008). Pollution with sulphate $\left(\mathrm{SO}_{4}^{2-}\right)$ may lead to increased $\mathrm{P}$ availability, by the interaction between produced sulphide $\left(\mathrm{H}_{2} \mathrm{~S}\right)$ and Fe-P cycling (Sperber, 1958; Roden and Edmonds, 1997; Lamers et al., 1998, 2002a; Zak et al., 2006) and by competition between $\mathrm{SO}_{4}^{2-}$ and phosphate $\left(\mathrm{PO}_{4}^{3-}\right)$ for anion binding sites (Caraco et al., 1989). $\mathrm{As} \mathrm{SO}_{4}^{2-}$ reduction generates alkalinity, decomposition and mineralization may increase even further (Roelofs, 1991; Smolders et al., 2006). The extent of $\mathrm{P}$ mobilization and ammonium $\left(\mathrm{NH}_{4}^{+}\right)$accumulation, and the possible additional effect of $\mathrm{SO}_{4}^{2-}$ during flooding largely depend on soil quality (Loeb et al., 2007). High levels of dissolved $\mathrm{Fe}$ can bind both $\mathrm{PO}_{4}^{3-}$ and $\mathrm{H}_{2} \mathrm{~S}$, preventing P-related eutrophication and $\mathrm{H}_{2} \mathrm{~S}$ toxicity (Smolders et al., 1995; Lamers et al., 2001). The level of $\mathrm{PO}_{4}^{3-}$ mobilization has been shown to be related to the saturation of binding sites in the amorphous Fe pool rather than to the concentration of $\mathrm{PO}_{4}^{3-}$ (Young and Ross, 2001; Loeb et al., 2008a). Although phosphorous is also bound to $\mathrm{Al}$ and $\mathrm{CaCO}_{3}$, these fractions are redox independent (Boström, 1988; Lamers et al., 2002b, 2006; Geurts et al., 2008). If high concentrations of nitrate $\left(\mathrm{NO}_{3}^{-}\right)$are present, they can prevent the reduction of $\mathrm{Fe}$ and $\mathrm{SO}_{4}^{2-}$, as $\mathrm{NO}_{3}^{-}$is a more favourable electron acceptor acting as a redox buffer, and reduce $\mathrm{PO}_{4}^{3-}$ mobilization rates (Lucassen et al., 2004).

Both the level of eutrophication and the accumulation of potentially phytotoxic compounds may influence the vegetation of riverine wetlands by the die-off of characteristic species and development of fast-growing plants outcompet- ing others (Roelofs, 1991; Lamers et al., 1998; Kotowski et al., 2006; Geurts et al., 2008). On the other hand, eutrophication may also lead to higher biomass production rates, which diminish toxicity effects due to dilution of these compounds in tissues, or due to stronger rhizosphere oxidation (Geurts et al., 2009). The development is not only important with respect to biodiversity, but also with respect to the rate of land subsidence or land accretion (e.g. Rooth and Stevenson, 2000). In eutrophic systems, decomposition and land subsidence may dominate, while in less eutrophic systems, such as those dominated by Carex species, net carbon fixation may lead to land accretion (Portnoy, 1999).

The aim of this study was to investigate the possibility for the creation of permanently flooded wetlands (marshes) along rivers, in relation to flood water quality $\left(\mathrm{NO}_{3}^{-}, \mathrm{SO}_{4}^{2-}\right.$ ) and soil use (level of fertilization in the past). This measure is one of proposed strategies to counteract flooding risks; next to the creation of temporarily flooded areas for water storage during flood peaks which was investigated in our previous work (Banach et al., 2009b) and that of others (Antheunisse and Verhoeven, 2008). In order to study the effects of longterm flooding under controlled conditions, for which much less information is available in literature, a mesocosm design using intact sods was used. A period of 9 months was chosen as a minimum period necessary in order to cover winter, spring, summer and autumn. The results with respect to biogeochemistry (especially $\mathrm{C}, \mathrm{Fe}, \mathrm{P}, \mathrm{N}$ and $\mathrm{S}$ cycling) and vegetation development will be discussed in relation to water management and nature management. In addition, we will compare both management strategies.

\section{Materials and methods}

\subsection{Field information}

The location where the sods were collected, Kosiorów village $\left(51^{\circ} 13^{\prime} \mathrm{N} ; 21^{\circ} 51^{\prime} \mathrm{E}\right.$; Fig. 1), is located close to the Chodelka River, a tributary of the Vistula River in Poland. This site was selected because of the plans of the local authorities to create a retention reservoir in this area to avoid flooding risks, as the Chodelka River is known to take backflowing water from the Vistula during high peaks of water discharge (Banach et al., 2009b). Along this river there are several meadows which show different cultivation histories depending on the preferences of their owners. Two neighbouring meadows showing exactly the same hydrology were selected of which one is heavily fertilized (with commercial fertilizer) and mown twice a year for hay-making (referred to as hayland, HAY), whereas the other is less fertilized and used only for grazing (pasture, PAS) at a low density of 1 animal per hectare.

Both meadows have the same geological origin and show a peaty soil type (upper $20 \mathrm{~cm}$ : $40-50 \%$ organic matter; with the inorganic fraction comprising $38-44 \%$ sand, $8-12 \%$ silt 
and $4 \%$ clay, Banach et al., 2009b), with the average water table $30 \mathrm{~cm}$ below soil surface leading to the partial oxidation of the top layer. Both soils are, however, nutrientrich, as concentrations of plant available $\mathrm{P}$ (Olsen $\mathrm{P}$ ) and $\mathrm{NO}_{3}^{-}$are very high in both soils (Banach et al., 2009b). In addition, total concentrations of $\mathrm{S}$ and $\mathrm{Fe}$ are high. There were significant differences between these soils with respect to moisture, organic matter content, concentrations of total $\mathrm{S}, \mathrm{NO}_{3}^{-}$, Olsen $\mathrm{P}$, labile $\mathrm{P}$ and $\mathrm{Fe} / \mathrm{Al}$ bound $\mathrm{P}$ fractions (Table 1). The HAY soils have been more strongly decomposed as a result of fertilization. At the onset of the experiment, both locations were covered by species-rich terrestrial vegetation dominated by Deschampsia cespitosa L. and Holcus lanatus L. (Table 2).

\subsection{Experimental design}

For studying the effects of long-term inundation with stagnating water, 40 sods $(30 \times 30 \times 15 \mathrm{~cm})$ were collected in total in autumn, with standing vegetation. After transportation to the Netherlands in plastic containers (to avoid desiccation), the sods were placed in a greenhouse. Each sod was fitted into a separate glass container $(25 \times 25 \times 30 \mathrm{~cm})$ at an air humidity of 40-90\%, under natural light and temperature (ranging between $5-41^{\circ} \mathrm{C}$ during the experiment) conditions following the outside diurnal and seasonal changes of light and temperature. The sides of the compartments were covered with black foil to avoid light influence on the sides of the soil.

Four different floodwater mixtures were prepared based on field data (water quality of the Chodelka and Vistula River) including a treatment with increased concentrations of nitrate $(\mathrm{N})$, sulphate $(\mathrm{S})$ or their combination $(\mathrm{SN})$, all at the level of $1000 \mu \mathrm{moll}^{-1}$. The control (Cfl) had pristine river water quality characterized by low levels of nutrients (Table 3), without the addition of phosphate. In addition, non flooded, moist controls were used $(\mathrm{Cm})$ as a contrast. Each treatment consisted of 4 replicates which were randomly distributed over the 40 units ( 20 per meadow type). The sods were kept inundated at $20 \mathrm{~cm}$ above soil level for 9 months (January till November) and if necessary adequate volumes of floodwater were added to maintain the desired water column. Non flooded controls were watered with artificial rainwater containing $5 \mathrm{mg} \mathrm{l}^{-1}$ of sea-salt, (Wiegandt $\mathrm{GmbH}$, Krefeld, Germany) in order to keep the groundwater level at $10 \mathrm{~cm}$ below soil surface to avoid desiccation of the sods during this period.

\subsection{Measurements and chemical analyses}

Soil samples were analysed for soil moisture percentage (drying samples at $105^{\circ} \mathrm{C}$ for $24 \mathrm{~h}$ ) and organic matter content (loss-on-ignition, $550^{\circ} \mathrm{C}, 4 \mathrm{~h}$ ). Levels of nutrients were examined in fresh soil samples (corrected afterwards for moisture content) by extraction: Olsen P (as an estimate of

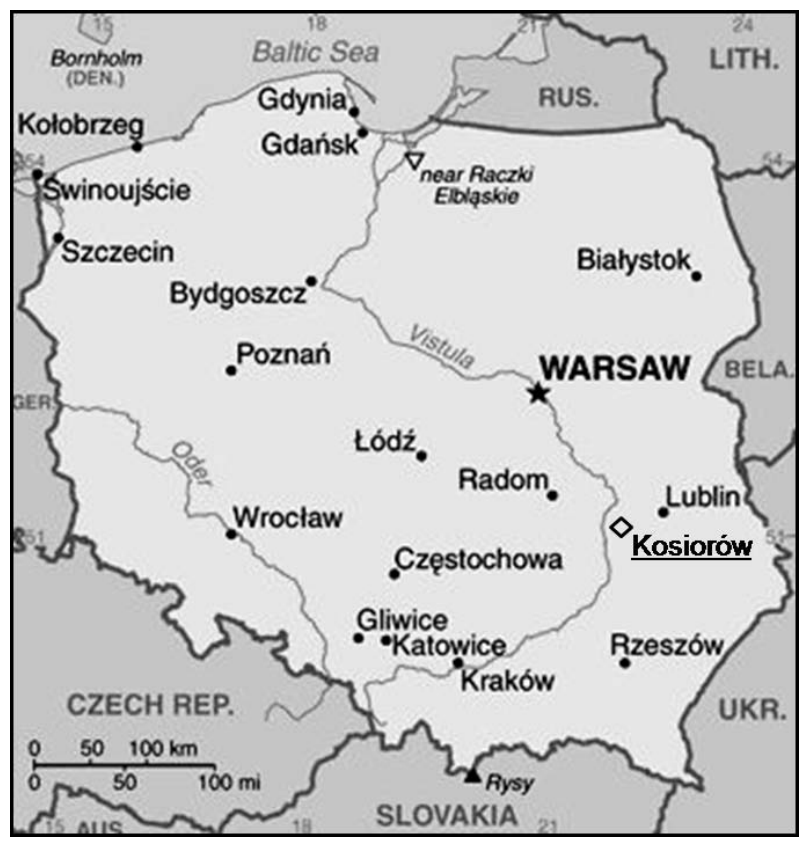

Fig. 1. Location of Kosiorów, the sampling area (diamond) in Poland.

Table 1. Characteristics of both tested soils $\left(\mu \mathrm{mol} 1^{-1}\right.$ of bulk soil except for moisture and organic matter, which are in \%).

\begin{tabular}{lccccc}
\hline $\begin{array}{l}\text { Characteristics } \\
(\text { mean } \pm \text { SEM })\end{array}$ & \multicolumn{5}{c}{ Hayland $\begin{array}{c}\text { Poil from } \\
\text { Pasture }\end{array}$} \\
\hline Moisture & 37 & $(2)$ & 50 & $(2)$ & $* * *$ \\
Organic matter & 41 & $(3)$ & 54 & $(1)$ & $* * *$ \\
$\mathrm{pH}$ & 6.2 & $(0.1)$ & 6.4 & $(0.2)$ & $\mathrm{NS}$ \\
Total S & 52321 & $(4376)$ & 40858 & $(1776)$ & $*$ \\
$\mathrm{NO}_{3}^{-\mathrm{a}}$ & 946 & $(107)$ & 2236 & $(232)$ & $* * *$ \\
$\mathrm{NH}_{4}^{+b}$ & 279 & $(76)$ & 180 & $(24)$ & NS \\
Olsen P & 3818 & $(435)$ & 1863 & $(238)$ & $* * *$ \\
Total P & 10508 & $(886)$ & 8833 & $(482)$ & NS \\
Amorphous Fe & 76671 & $(8668)$ & 78140 & $(3393)$ & NS \\
Total Fe & 117560 & $(10480)$ & 100982 & $(5094)$ & NS \\
Total Fe:P & 11.0 & $(0.9)$ & 11.6 & $(0.4)$ & NS \\
Total (Fe-S):P & 6.1 & $(0.6)$ & 6.9 & $(0.4)$ & NS \\
Labile P fraction & 90.4 & $(10)$ & 15.8 & $(1.3)$ & $* * *$ \\
Fe/Al bound P & 1631 & $(147)$ & 760 & $(37)$ & $* * *$ \\
Ca bound P & 3178 & $(417)$ & 2981 & $(119)$ & NS \\
Organic P & 5609 & $(484)$ & 5077 & $(383)$ & NS \\
\hline
\end{tabular}

${ }^{\mathrm{a}}$ Water extractable nitrate, ${ }^{\mathrm{b}} \mathrm{NaCl}$ extractable ammonium *** $p<0.001, * * p<0.01, * p<0.05$, NS not significant

plant available $\mathrm{P}$, Olsen et al., 1954), NaCl-extractable ammonium and water extraction (Banach et al., 2009b). The concentration of amorphous iron was estimated by oxalate extraction (Schwertmann, 1964) whilst soil P fractions were estimated using the method described by Golterman (1996). In addition, total element concentrations were measured after digestion of $200 \mathrm{mg}$ samples in a mixture of concentrated $\mathrm{HNO}_{3}$ and $30 \% \mathrm{H}_{2} \mathrm{O}_{2}(4+1 \mathrm{ml})$ using a Milestone microwave MLS 1200 Mega system (Sorisole, Italy). 

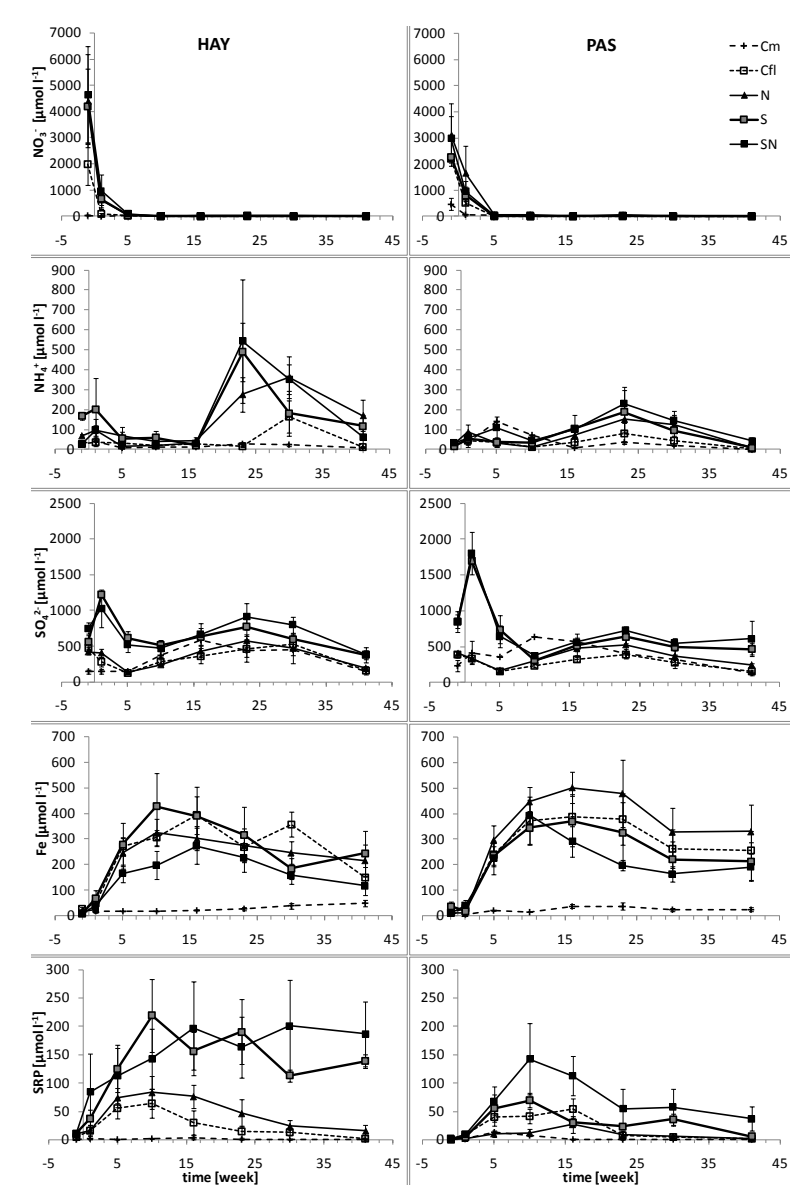

Fig. 2. Changes in concentrations of selected variables in sediment pore water - means $\pm \operatorname{SEM}(n=4)$. The week number refers to the time after the onset of flooding.

Two sediment pore water samplers (Rhizon SMS-10 cm; Eijkelkamp Agrisearch Equipment, Giesbeek, the Netherlands) were placed diagonally at $5-10 \mathrm{~cm}$ depth connected to black silicone tubes for monitoring of sediment pore water chemistry in each container. Samples were collected anaerobically by means of $50 \mathrm{ml}$ vacuumed syringes. After discarding the first $10 \mathrm{ml}$ (stagnant water), collected subsamples were pooled for other measurements.

Sediment pore water $(50 \mathrm{ml})$ and surface water $(500 \mathrm{ml})$ samples were collected monthly. Additional pore water samples were collected three times (Fig. 2) for determination levels of total inorganic carbon (TIC, sum of $\mathrm{CO}_{2}$ and $\mathrm{HCO}_{3}^{-}$).

Free (dissolved) sulphide $\left(\mathrm{H}_{2} \mathrm{~S}\right)$ in sediment pore water was estimated in $10.5 \mathrm{ml}$ of subsample fixed immediately after collection with $10.5 \mathrm{ml}$ of sulphide antioxidant buffer (Van Gemerden, 1984). For this measurement a sulphide ionselective Ag-electrode and a double junction calomel reference electrode were used (Roelofs, 1991).

Titration of $10 \mathrm{ml}$ of sample with $0.01 \mathrm{M} \mathrm{HCl}$ down to $\mathrm{pH}$ 4.2 allowed us to determine alkalinity (TIM800 pH-meter with the above mentioned $\mathrm{pH}$-electrode and an ABU901 Au-
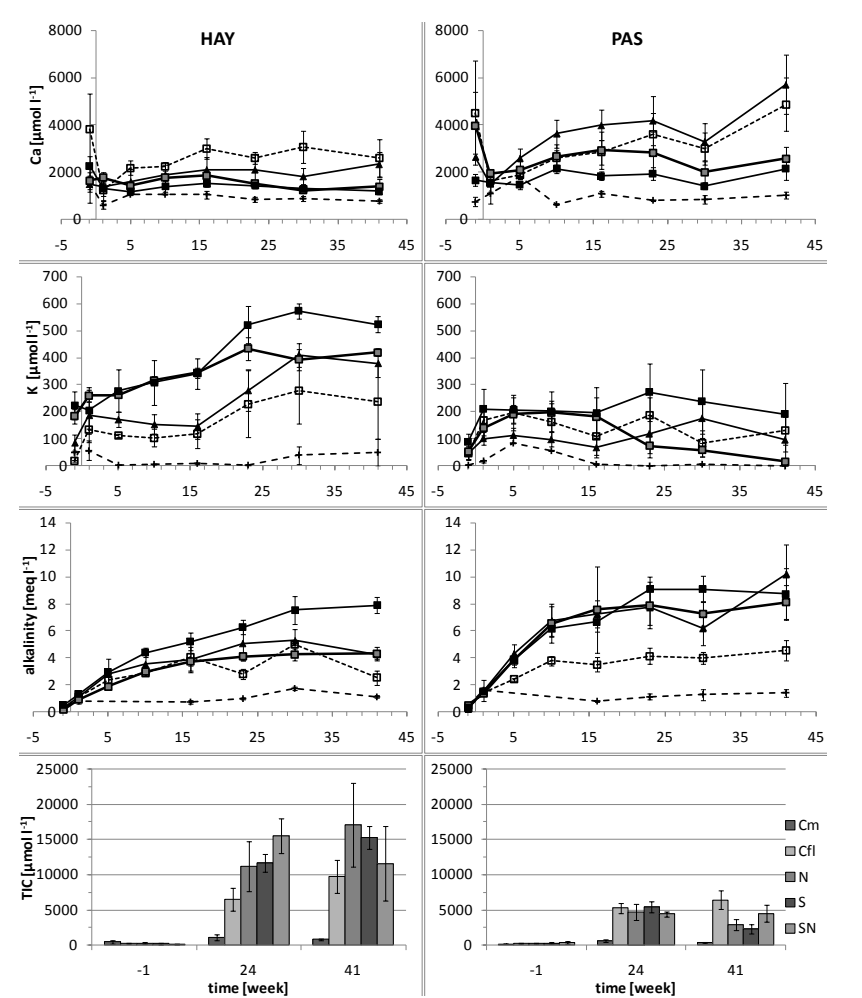

Fig. 2. Continued.

toburette, Radiometer Copenhagen, Denmark) preceded by $\mathrm{pH}$ measurement. In surface water, turbidity (nephelometric turbidity units, NTU) was estimated using a WTW turbidity meter Turb550 (Weilheim, Germany). The remaining volumes were filtered over a Whatman microfiber filter type GF/C (Whatman, Brentford, UK) after which citric acid was added (to a final concentration of $0.125 \mathrm{~g}^{-1}$ ) to avoid precipitation of metals, and stored in $100 \mathrm{ml}$ iodated polyethylene bottles at $-28^{\circ} \mathrm{C}$ until further analysis.

The concentrations of $\mathrm{NO}_{3}^{-}, \mathrm{NH}_{4}^{+}$and soluble reactive phosphorus (SRP) were determined by means of an Auto Analyser 3 System (Bran and Luebbe, Norderstedt, Germany) according to standard procedures (Banach et al., 2009b) followed by correction for colour (at $450 \mathrm{~nm}$ ) caused by humic substances (Shizmadzu UV-120-01 spectrophotometer, Kyoto, Japan). The total concentrations of $\mathrm{Fe}, \mathrm{Ca}$, $\mathrm{K}, \mathrm{P}$, and $\mathrm{S}$ were analysed by means of inductively coupled plasma optical emission spectrometry (ICP-OES, IRIS Intrepid II, Thermo Electron Corporation, Franklin, MA, USA). At the (relatively high) concentrations used in this experiment the total $\mathrm{S}$ concentrations in the water layer provided a good estimate of $\mathrm{SO}_{4}^{2-}$, because only a small percentage of the element is present in organic form. This was verified by parallel analysis of various samples for different treatments using capillary ion analysis (Waters Technologies), in which $\mathrm{SO}_{4}^{2-}$ concentrations were shown to match the total $\mathrm{S}$ concentrations within the uncertainty of both methods. 
Table 2. Plant species present on sods from hayland and pasture (average abundance, \%) at the beginning and the end the experiment. Capital letters after species name represent groups $-\mathrm{H}-$ herbs, $\mathrm{G}$ - grasses, $\mathrm{C}-$ Carex species.

\begin{tabular}{|c|c|c|c|c|c|}
\hline \multirow{2}{*}{ Species } & \multirow{2}{*}{ Family } & \multicolumn{2}{|l|}{ Hayland } & \multicolumn{2}{|l|}{ Pasture } \\
\hline & & before & after & before & after \\
\hline Achillea millefolium $(\mathrm{H})$ & Asteraceae & $0-25$ & $0-5$ & - & - \\
\hline Agrostis spp. (G) & Poaceae & $0-1$ & $0-50$ & 0 & $0-5$ \\
\hline Anthoxanthum spp. (G) & Poaceae & - & - & 0 & $0-1$ \\
\hline Arabidopsis suecia $(\mathrm{H})$ & Brassiceae & 0 & $0-5$ & $0-1$ & $0-5$ \\
\hline Cardamine spp. (H) & Brassiceae & 0 & $0 ;<1$ & $0-1$ & 0 \\
\hline Carex hirta $(\mathrm{C})$ & Cyperaceae & 0 & $0-40$ & $0-1$ & $10-50$ \\
\hline Carex acuta. (C) & Cyperaceae & 0 & $0-50$ & $0-1$ & $5-50$ \\
\hline Centaurea jacea $(\mathrm{H})$ & Asteraceae & $0-1$ & 0 & - & - \\
\hline Deschampsia cespitosa $(\mathrm{G})$ & Poaceae & $5-75$ & $0-5$ & $5-75$ & $0-50$ \\
\hline Festuca rubra $(\mathrm{G})$ & Poaceae & $0-5$ & $0-50$ & $5-25$ & $0-1$ \\
\hline Filipendula ulmaria $(\mathrm{H})$ & Rosaceae & - & - & $0-1$ & 0 \\
\hline Galium boreale $(\mathrm{H})$ & Rubiaceae & $0-5$ & $0-10$ & $0-5$ & $0-10$ \\
\hline Galium uliginosum $(\mathrm{H})$ & Rubiaceae & 0 & $0-5$ & $0-75$ & $0-50$ \\
\hline Galium spp. (H) & Rubiaceae & - & - & $<1$ & $0-5$ \\
\hline Holcus lanatus $(\mathrm{G})$ & Poaceae & $5-50$ & $0-5$ & 0 & $0-10$ \\
\hline Lathyrus pratensis $(\mathrm{H})$ & Fabaceae & $0-1$ & $0-5$ & $0-1$ & $0-1$ \\
\hline Leontodon autumnalis $(\mathrm{H})$ & Asteraceae & 0 & $0-1$ & $0-25$ & $0-1$ \\
\hline Linaria vulgaris $(\mathrm{H})$ & Scrophulariaceae & $0-1$ & $0-5$ & $0-1$ & $0-5$ \\
\hline Lythrum salicaria $(\mathrm{H})$ & Lythraceae & 0 & $0-40$ & 0 & $0-5$ \\
\hline Mentha arvensis $(\mathrm{H})$ & Lamiaceae & 0 & $0-5$ & - & - \\
\hline Plantago lanceolata $(\mathrm{H})$ & Plantaginaceae & $0-1$ & $0-10$ & $0-1$ & $0-50$ \\
\hline Plantago major $(\mathrm{H})$ & Plantaginaceae & - & - & 0 & $0-1$ \\
\hline Poa pratensis $(\mathrm{G})$ & Poaceae & $0-5$ & $0-50$ & - & - \\
\hline Potentilla reptans $(\mathrm{H})$ & Rosaceae & - & - & $5-25$ & $0-10$ \\
\hline Ranunculus acris $(\mathrm{H})$ & Ranunculaceae & 0 & $0-5$ & 0 & $0-50$ \\
\hline Ranunculus auricomus $(\mathrm{H})$ & Ranunculaceae & $0-1$ & $0-1$ & $0-25$ & $0-1$ \\
\hline Ranunculus repens $(\mathrm{H})$ & Ranunculaceae & $0-1$ & $0-5$ & 0 & $0-1$ \\
\hline Rumex acetosa $(\mathrm{H})$ & Polygonaceae & $0-1$ & 0 & $0-1$ & 0 \\
\hline Sanguisorba officinalis $(\mathrm{H})$ & Rosaceae & - & - & $0-5$ & $0-1$ \\
\hline Stellaria graminea $(\mathrm{H})$ & Caryophyllaceae & $0-5$ & $0-1$ & $0-5$ & $0-5$ \\
\hline Taraxacum officinale $(\mathrm{H})$ & Asteraceae & $0-1$ & $0-1$ & - & - \\
\hline Trifolium repens $(\mathrm{H})$ & Fabaceae & $0-1$ & 0 & $0-1$ & 0 \\
\hline Veronica chamaedrys $(\mathrm{H})$ & Scrophulariaceae & - & - & $0-1$ & 0 \\
\hline Vicia spp. $(\mathrm{H})$ & Fabaceae & - & - & $0-1$ & 0 \\
\hline
\end{tabular}

Total concentrations of TIC were determined by collecting pore water samples into vacuumed infusion flasks $(30 \mathrm{ml})$ and correcting for the headspace volume. Concentrations of gases were measured using an infrared gas analyser (ABB Advance Optima IRGA, Zürich, Switzerland).

\subsection{Vegetation description}

The vegetation present on the sods was described in detail (number of individuals and their cover for each species) before the onset of submergence and at the end of the experiment. We divided the plants into 3 groups: grasses (G), Carex species (C) and herbs (H) (see Table 2). In addition, we determined the total cover of plants and algae (in \%) during water sampling. Vegetation and algae were harvested 6 months after the onset of submergence and at the end of the study to be able to quantify biomass production rather than standing stock. Collected material was dried at $70^{\circ} \mathrm{C}$ for $48 \mathrm{~h}$, weighed (dry weight) and analyzed for total concentrations of selected elements (ICP, see above) after microwave digestion (see above). Total concentrations of $\mathrm{C}$ and $\mathrm{N}$ were estimated in $2 \mathrm{mg}$ of homogenized dry material using a Carlo Erba NA1500 elemental analyzer (Thermo Fisher Scientific, MA, USA). For nutrient ratios, weighted means of the separate plant groups were used. 


\subsection{Data Analysis}

All data were statistically processed by means of SPSS for Windows (SPSS 15.0, 2006, Chicago, IL, USA). Biogeochemical variables were $\ln (\mathrm{x}+1)$ transformed in order to make the data fit better to the normal distribution and to make the variances less dependent of the sample means. Vegetation cover and algae cover were arcsin sqrt transformed and species number was $\log (\mathrm{x}+1)$ transformed.

Relationships between variables (only for flooded) were tested by calculating Spearman's rho correlation coefficients $\left(r_{s}\right)$ due to differences between sizes of variables, and regression lines were fitted (with $R^{2}$ statistic).

Changes in sediment- and water-related variables as well as vegetation and algae data in time were tested in a stepwise procedure. First, a comparison of flooded versus nonflooded treatments was performed, followed by a comparison between all flooded treatments. A repeated measures ANOVA, model mixed designs (GLM 5), procedure was used in both cases for both tested meadows. If the assumption of sphericity was not met, an appropriate correction was used according to the values of the Greenhouse or HuynhFeldt test statistics (Field, 2005). Tukey HSD (homogeneity of variances assumed) or Games-Howell procedure (homogeneity of variances not assumed) were used as post hoc tests. In addition, data from the end of the study were analyzed by means of ANOVA (with Tukey or Gamess-Howell post-hoc tests). The same test was used for plant tissue nutrient ratios.

Differences between soil characteristics were assessed using independent samples t-test. Significance was accepted at $p$-value $\leq 0.05$. For better clarity, all data are presented as means of non-transformed variables \pm standard error of the mean (SEM).

\section{Results}

\subsection{Soil response to flooding}

Initially (one week before flooding), tested soils had a $\mathrm{pH}$ of 5-6 with low alkalinity $\left(<0.5 \mathrm{meq}^{-1}\right)$ and low levels of $\mathrm{NH}_{4}^{+}, \mathrm{Fe}^{2+}, \mathrm{SRP}$ and TIC in the sediment pore water. Concentrations of $\mathrm{NO}_{3}^{-}$were high and differed between both meadows: around $5000 \mu \mathrm{mol}^{-1}$ in the hayland (HAY) and $3000 \mu \mathrm{moll}^{-1}$ for the pasture (PAS). Concentrations of $\mathrm{SO}_{4}^{2-}$ were below $1000 \mu \mathrm{mol} l^{-1}$ in both soils (Fig. 2).

The dissolved $\mathrm{NO}_{3}^{-}$pool in sediment pore water declined by 3-5 times one week after inundation remaining significantly higher than $\mathrm{Cm}$ (Tables 4,5 ), without effect of soil use $(p=0.72)$. Concentrations of $\mathrm{NH}_{4}^{+}$in sediment pore water showed an opposite trend in time compared to $\mathrm{NO}_{3}^{-}$, interacting with soil use $(t \times \mathrm{L}$, Table 5$)$ by a strong increase to a peak of 300-600 $\mu \mathrm{moll}^{-1}$ in HAY and $100-200 \mu \mathrm{moll}^{-1}$ in PAS after 16 weeks (Table 5).
Table 3. Chemical composition $\left(\mu \mathrm{mol}^{-1}\right)$ of artificial flood-water for each treatment. S: sulphate, N: nitrate, Cfl: flooded control.

\begin{tabular}{lcccc}
\hline Salt & SN & S & N & Cfl \\
\hline $\mathrm{CaCl}_{2} \cdot 2 \mathrm{H}_{2} \mathrm{O}$ & 610 & 610 & 610 & 610 \\
$\mathrm{KCl}$ & 240 & 240 & 240 & 240 \\
$\mathrm{MgCl}_{2} \cdot 6 \mathrm{H}_{2} \mathrm{O}$ & 75 & 75 & 75 & 75 \\
$\mathrm{Na}_{2} \mathrm{SO}_{4}$ & 1000 & 1000 & 100 & 100 \\
$\mathrm{NaNO}_{3}$ & 1000 & 25 & 1000 & 25 \\
$\mathrm{NaHCO}_{3}$ & 2000 & 2000 & 2000 & 2000 \\
$\mathrm{NaCl}$ & 0 & 975 & 1800 & 2775 \\
\hline
\end{tabular}

Concentration of $\mathrm{SO}_{4}^{2-}$ in sediment pore water differed in time interacting with flooding treatment and water quality $(t \times \mathrm{I}$ and $t \times \mathrm{W}$, Tables 4, 5 and Fig. 2). Initial higher levels above $1 \mathrm{mmoll}^{-1}$ in $\mathrm{S}$ and $\mathrm{SN}$ treatments were further reduced to values between $500-1000 \mu \mathrm{moll}^{-1}$. We found significantly higher values for $\mathrm{SN}$ and $\mathrm{S}$ treatments in comparison to $\mathrm{N}$, Cfl, and $\mathrm{Cm}$, which did not differ from each other and remained below $500 \mu \mathrm{mol}^{-1}$. We did not observe differences in $\mathrm{SO}_{4}^{2-}$ between soils $(p=0.89$, Table 4$)$. While $\mathrm{Cm}$ did not show $\mathrm{H}_{2} \mathrm{~S}$ accumulation in the sediment pore water, higher levels of this compound $\left(2-12 \mu \mathrm{mol}^{-1}\right)$ were recorded in S and SN treatments (Table 5).

Inundation led to strong mobilization of $\mathrm{Fe}^{2+}$ into sediment pore water after 5 weeks with a peak of 400$500 \mu \mathrm{moll}^{-1}$ after 9 (HAY) and 15 (PAS) weeks (Fig. 2). There were no significant differences between treatments ( $p=0.41$, Table 5). There was a concomitant and rapid SRP mobilization to extremely high levels of $50-100 \mu \mathrm{moll}^{-1}$ one week after flooding. The amount of mobilized SRP depended on water quality; SRP levels in sediment pore water were higher for $\mathrm{S}$ and $\mathrm{SN}$ than for the others. The response differed between both tested soils: HAY showed continuous release of SRP with maximum of $200 \mu \mathrm{moll}^{-1}$, while for PAS the concentration of SRP decreased after 12 weeks from 150 to $50 \mu \mathrm{moll}^{-1}$ at the end of the experiment, and became comparable to levels in other flooded treatments (Fig. 2, Table 5).

Inundation led to elevated levels of $\mathrm{Ca}^{2+}$ in sediment pore water, 2-6 times higher in comparison to about $1 \mathrm{mmol}^{-1}$ in $\mathrm{Cm}$, changing over time (Fig. 2). S presence led to lower concentrations of $\mathrm{Ca}^{2+}$ in sediment pore water as compared to $\mathrm{Cm}$ and $\mathrm{N}$ treatments. $\mathrm{K}^{+}$concentrations in sediment pore water increased to $200-300 \mu \mathrm{mol}^{-1}$ after flooding in comparison to $\mathrm{Cm}$, with higher values for HAY than for PAS (Fig. 2). In general, water quality had no significant effect of $\mathrm{K}^{+}$concentrations in sediment pore water $(p=0.21$, Table 5).

Sediment pore water $\mathrm{pH}$ increased very fast after inundation (Table 4) to values of 6.5-7.5 and remaining significantly higher in comparison to $\mathrm{Cm}$ during the whole period. We observed a stronger increase of $\mathrm{pH}$ in HAY than 
Table 4. Results of time ( $t$ ) effects and their interactions with land use (L) for flooded versus non-flooded soils (I), examined by means of GLM5 analysis. $F$-ratios and their levels of significance are given $(n=4)$. Bold values indicate significant differences.

\begin{tabular}{|c|c|c|c|c|c|c|c|}
\hline Sediment pore water & $t$ & $\mathrm{~L}$ & I & $t \times \mathrm{L}$ & $t \times \mathrm{I}$ & $\mathrm{L} \times \mathrm{I}$ & $t \times \mathrm{L} \times \mathrm{I}$ \\
\hline $\mathrm{pH}$ & $21.50 * * *$ & $4.61 *$ & $44.19 * * *$ & $1.96^{\mathrm{NS}}$ & $12.13 * * *$ & $2.34^{\mathrm{NS}}$ & $1.25^{\mathrm{NS}}$ \\
\hline Alkalinity & $89.55 * * *$ & $1.75^{\mathrm{NS}}$ & $54.72 * * *$ & $1.87^{\mathrm{NS}}$ & $32.56 * * *$ & $0.49^{\mathrm{NS}}$ & $0.53^{\mathrm{NS}}$ \\
\hline TIC & $101.47 * * *$ & $12.13 * *$ & 82.01*** & $2.84^{\mathrm{NS}}$ & $33.57 * * *$ & $0.02^{\mathrm{NS}}$ & $2.24^{\mathrm{NS}}$ \\
\hline $\mathrm{NO}_{3}^{-}$ & $29.85 * * *$ & $2.99^{\mathrm{NS}}$ & $28.92 * * *$ & $2.67^{\mathrm{NS}}$ & $9.96 * * *$ & $1.37^{\mathrm{NS}}$ & $1.90^{\mathrm{NS}}$ \\
\hline $\mathrm{NH}_{4}^{+}$ & $2.17^{\mathrm{NS}}$ & $0.00^{\mathrm{NS}}$ & $1.30^{\mathrm{NS}}$ & $0.10^{\mathrm{NS}}$ & $2.56^{\mathrm{NS}}$ & $0.41^{\mathrm{NS}}$ & $0.55^{\mathrm{NS}}$ \\
\hline SRP & $4.70 * *$ & $2.20^{\mathrm{NS}}$ & $27.71 * * *$ & $0.30^{\mathrm{NS}}$ & $4.21 * *$ & $2.59^{\mathrm{NS}}$ & $0.23^{\mathrm{NS}}$ \\
\hline Total Fe & $21.26 * * *$ & $1.15^{\mathrm{NS}}$ & $42.61 * * *$ & $0.65^{\mathrm{NS}}$ & $5.32 * *$ & $0.98^{\mathrm{NS}}$ & $0.17^{\mathrm{NS}}$ \\
\hline $\mathrm{K}^{+}$ & $5.31 * *$ & $8.67 * *$ & 43.41*** & $3.12 *$ & $3.26 *$ & $0.14^{\mathrm{NS}}$ & $0.55^{\mathrm{NS}}$ \\
\hline $\mathrm{Ca}^{2+}$ & $3.31 *$ & $3.51^{\mathrm{NS}}$ & $42.54 * * *$ & $0.87^{\mathrm{NS}}$ & $0.34^{\mathrm{NS}}$ & $1.67^{\mathrm{NS}}$ & $1.40^{\mathrm{NS}}$ \\
\hline $\mathrm{SO}_{4}^{2-}$ & $7.93 * * *$ & $0.54^{\mathrm{NS}}$ & $4.25 *$ & $1.90^{\mathrm{NS}}$ & $7.51 * * *$ & $0.41^{\mathrm{NS}}$ & $0.81^{\mathrm{NS}}$ \\
\hline $\mathrm{H}_{2} \stackrel{4}{\mathrm{~S}}$ & $5.65 * *$ & $0.15^{\mathrm{NS}}$ & $17.97 * * *$ & $0.38^{\mathrm{NS}}$ & $0.78^{\mathrm{NS}}$ & $0.00^{\mathrm{NS}}$ & $0.72^{\mathrm{NS}}$ \\
\hline
\end{tabular}

$t$ - time, L - land use, I - inundation, $* * * p<0.001, * * p<0.01, * p<0.05$, NS not significant.

Table 5. Results of time $(t)$ effects and their interactions with land use (L), and water quality (W) for flooded soils, examined by means GLM5 analysis. $F$-ratios and their levels of significance are given $(n=4)$. Bold values indicate significant differences.

\begin{tabular}{|c|c|c|c|c|c|c|c|}
\hline & $t$ & $\mathrm{~L}$ & W & $t \times \mathrm{L}$ & $t \times \mathrm{W}$ & $\mathrm{Lx} W$ & $t \times \mathrm{L} \times \mathrm{W}$ \\
\hline \multicolumn{8}{|c|}{ Sediment pore water } \\
\hline $\mathrm{pH}$ & $96.33 * * *$ & $0.29^{\mathrm{NS}}$ & $5.93 * *$ & $3.08^{*}$ & $1.44^{\mathrm{NS}}$ & $3.35^{*}$ & $0.97^{\mathrm{NS}}$ \\
\hline Alkalinity & $220.40 * * *$ & $10.21 * *$ & $3.85^{*}$ & $2.85 *$ & $1.93^{\mathrm{NS}}$ & $1.20^{\mathrm{NS}}$ & $0.58^{\mathrm{NS}}$ \\
\hline TIC & $225.04 * * *$ & $9.68 * *$ & $0.12^{\mathrm{NS}}$ & $9.80 * * *$ & $0.72^{\mathrm{NS}}$ & $1.09^{\mathrm{NS}}$ & $1.08^{\mathrm{NS}}$ \\
\hline $\mathrm{NO}_{3}^{-}$ & $144.81 * * *$ & $0.13^{\mathrm{NS}}$ & $7.73 * *$ & $3.08 *$ & $0.88^{\mathrm{NS}}$ & $1.21^{\mathrm{NS}}$ & $0.62^{\mathrm{NS}}$ \\
\hline $\mathrm{NH}_{4}^{+}$ & $13.03 * * *$ & $4.08^{\mathrm{NS}}$ & $2.35^{\mathrm{NS}}$ & $3.19 * *$ & $1.12^{\mathrm{NS}}$ & $1.63^{\mathrm{NS}}$ & $0.91^{\mathrm{NS}}$ \\
\hline SRP & $34.26 * * *$ & $32.53 * * *$ & $12.74 * * *$ & $1.74 * *$ & $2.16 *$ & $1.93^{\mathrm{NS}}$ & $1.13^{\mathrm{NS}}$ \\
\hline Total Fe & $209.46 * * *$ & $0.16^{\mathrm{NS}}$ & $1.01^{\mathrm{NS}}$ & $2.49 *$ & $1.17^{\mathrm{NS}}$ & $0.31^{\mathrm{NS}}$ & $1.45^{\mathrm{NS}}$ \\
\hline $\mathrm{K}^{+}$ & $5.84 * *$ & $12.96 * *$ & $1.63^{\mathrm{NS}}$ & $7.11 * *$ & $0.72^{\mathrm{NS}}$ & $0.59^{\mathrm{NS}}$ & $0.49^{\mathrm{NS}}$ \\
\hline $\mathrm{Ca}^{2+}$ & $5.64 * *$ & $15.22 * *$ & 4.04* & $2.53 *$ & $1.61^{\mathrm{NS}}$ & $0.79^{\mathrm{NS}}$ & $0.80^{\mathrm{NS}}$ \\
\hline $\mathrm{SO}_{4}^{2-}$ & $30.10 * * *$ & $0.02^{\mathrm{NS}}$ & $62.77 * * *$ & $2.94 * *$ & $4.46 * * *$ & $0.21^{\mathrm{NS}}$ & $0.79^{\mathrm{NS}}$ \\
\hline $\mathrm{H}_{2} \stackrel{4}{\mathrm{~S}}$ & $13.42 * * *$ & $0.68^{\mathrm{NS}}$ & $30.44 * * *$ & $2.22^{\mathrm{NS}}$ & $1.29^{\mathrm{NS}}$ & $1.48^{\mathrm{NS}}$ & $1.10^{\mathrm{NS}}$ \\
\hline \multicolumn{8}{|c|}{ Surface water } \\
\hline $\mathrm{pH}$ & $56.28 * * *$ & $3.23^{\mathrm{NS}}$ & $19.87 * * *$ & $2.39 *$ & $2.84 * *$ & $0.48^{\mathrm{NS}}$ & $0.34^{\mathrm{NS}}$ \\
\hline alkalinity & $148.81^{* * * *}$ & $8.59 * *$ & $27.09 * * *$ & $1.99^{\mathrm{NS}}$ & $7.58 * * *$ & $0.23^{\mathrm{NS}}$ & $0.57^{\mathrm{NS}}$ \\
\hline turbidity & $13.62 * * *$ & $23.59 * * *$ & $0.41^{\mathrm{NS}}$ & $0.63^{\mathrm{NS}}$ & $1.37^{\mathrm{NS}}$ & $2.14^{\mathrm{NS}}$ & $0.84^{\mathrm{NS}}$ \\
\hline $\mathrm{NO}_{3}^{-}$ & $190.71 * * *$ & $0.07^{\mathrm{NS}}$ & $14.38 * * *$ & $1.11^{\mathrm{NS}}$ & $1.72^{\mathrm{NS}}$ & $5.74 * *$ & $1.22^{\mathrm{NS}}$ \\
\hline $\mathrm{NH}_{4}^{+}$ & $2.42 *$ & $19.85 * * *$ & $23.53 * * *$ & $3.20 * *$ & $1.99 *$ & $4.54 *$ & $1.18^{\mathrm{NS}}$ \\
\hline SRP & $10.02 * * *$ & $14.37 * *$ & $9.41 * * *$ & $1.87^{\mathrm{NS}}$ & $2.56 *$ & $1.31^{\mathrm{NS}}$ & $0.95^{\mathrm{NS}}$ \\
\hline Total Fe & $93.12 * * *$ & $8.92 * *$ & $2.13^{\mathrm{NS}}$ & $4.68 * *$ & $2.94 * *$ & $1.22^{\mathrm{NS}}$ & $0.88^{\mathrm{NS}}$ \\
\hline $\mathrm{K}^{+}$ & $11.82 * * *$ & $12.18 * *$ & $0.78^{\mathrm{NS}}$ & $11.85 * * *$ & $1.47^{\mathrm{NS}}$ & $0.49^{\mathrm{NS}}$ & $0.40^{\mathrm{NS}}$ \\
\hline $\mathrm{Ca}^{2+}$ & $68.73 * * *$ & $2.86^{\mathrm{NS}}$ & $5.87 * *$ & $3.96 * *$ & $3.98 * * *$ & $0.07^{\mathrm{NS}}$ & $1.05^{\mathrm{NS}}$ \\
\hline $\mathrm{SO}_{4}^{2-}$ & $60.98 * * *$ & $5.01 *$ & $194.76 * * *$ & $2.82 *$ & $4.18 * * *$ & $2.49^{\mathrm{NS}}$ & $1.35^{\mathrm{NS}}$ \\
\hline
\end{tabular}

$t$ - time, $\mathrm{L}$ - land use, I - inundation, $\mathrm{W}-$ water quality, $* * * p<0.001, * * p<0.01, * p<0.05$, NS not significant

PAS and significant differences between water qualities: SN treatment had significantly higher $\mathrm{pH}$ for HAY, whilst PAS showed higher $\mathrm{pH}$ for $\mathrm{SN}, \mathrm{S}$ and $\mathrm{N}$ treatments in contrast to Cfl (Table 5). These changes in $\mathrm{pH}$ coincided with strong alkalinization of the sediment pore water during flooding reaching high levels, particularly for PAS soils and SN treatments (Fig. 2, Tables 4, 5). The increase of the alkalinity was related to the accumulation of TIC in the sediment pore 
A. M. Banach et al.: Effects of long-term flooding

water in time. Anaerobic soil conditions also led to $\mathrm{CH}_{4}$ accumulation in sediment pore water with maximum peaks of 200-1000 $\mu \mathrm{mol}^{-1}$ for all treatments. There were no effects of soil use ( $p=0.25)$, but $\mathrm{CH}_{4}$ concentrations were higher in $\mathrm{N}, \mathrm{S}$ and $\mathrm{SN}$ in comparison to $\mathrm{Cfl}$ (results not shown).

\subsection{Changes in water layer}

$\mathrm{NO}_{3}^{-}$concentrations in surface water differed only initially at one week after flooding due to treatment (Fig. 3, Table 5). There was a strong $\mathrm{NO}_{3}^{-}$reduction to levels comparable to $\mathrm{N}$-poor waters (lower than $40 \mu \mathrm{moll}^{-1}$ ), except for the end of the treatment period. In addition, $\mathrm{NH}_{4}^{+}$levels in the surface water increased (Fig. 3) differing between tested soils (Table 5). HAY soil showed much stronger $\mathrm{NH}_{4}^{+}$ mobilization (up to $\left.50 \mu \mathrm{moll}^{-1}\right)$ then PAS $\left(<20 \mu \mathrm{moll}^{-1}\right)$. Moreover, we observed a significant effect of water quality on $\mathrm{NH}_{4}^{+}$levels for HAY; the highest peak of $50 \mu \mathrm{mol} 1^{-1}$ was for SN followed by S, N (10-20 $\left.\mu \mathrm{moll}^{-1}\right)$ and Cfl $\left(<10 \mu \mathrm{mol}^{-1}\right)$ treatment (Table 5).

The concentrations of $\mathrm{SO}_{4}^{2-}$ in the surface water were related to both water composition and soil use (Tables 4, 5) decreasing from levels of $1200-1600 \mu \mathrm{moll}^{-1}$ to about $400 \mu \mathrm{moll}^{-1}$ (S and SN treatments), especially for HAY.

The concentrations of $\mathrm{Fe}^{2+}$ in the surface water differed between tested soils (Table 4): HAY showed stronger mobilization $\left(160 \mu \mathrm{moll}^{-1}\right)$ than PAS $\left(70 \mu \mathrm{moll}^{-1}\right)$. We did not detect significant differences between water quality treatments ( $p=0.12$, Fig. 3, Table 5).

The raised levels of SRP in the sediment pore water led to $P$ release into the surface water above, increasing over time with differential responses for both soils. HAY showed values up to $40-120 \mu \mathrm{mol}^{-1}$ for S and SN treatments (Fig. 3), in contrast to values of $20-50 \mu \mathrm{moll}^{-1}$ for PAS (S, SN). Treatments without $\mathrm{S}$ enrichment showed, however, much lower levels of SRP $\left(<15 \mu \mathrm{moll}^{-1}\right.$ in HAY and $<2 \mu \mathrm{moll}^{-1}$ in PAS). Flooding resulted in an increase of water turbidity to 15-25 NTU without significant effects of the water composition $(p=0.75)$, but with higher values for HAY than for PAS.

Concentrations of $\mathrm{Ca}^{2+}$ in the surface water increased 22.5 times above the initial value of $1 \mathrm{mmol}^{-1}$ during inundation without effect of soil use ( $p=0.10$, Table 5). However, water quality influenced $\mathrm{Ca}^{2+}$ levels favouring its release at low $\mathrm{S}$ levels (Fig. 3). Also $\mathrm{K}^{+}$concentrations in surface water significantly differed over time (Table 5 ), with diverse patterns for both soils; there was an increase in HAY and decrease in PAS. We did not find a significant influence of water quality on $\mathrm{K}^{+}$mobilization to the surface water $(p=0.52)$.

The $\mathrm{pH}$ of the surface water rose from 7 to $7.5-8$; the highest value was measured for SN (Table 5). In addition, there was a strong alkalinisation of water layer especially in $\mathrm{SN}$ treatments (Fig. 3, Table 5).
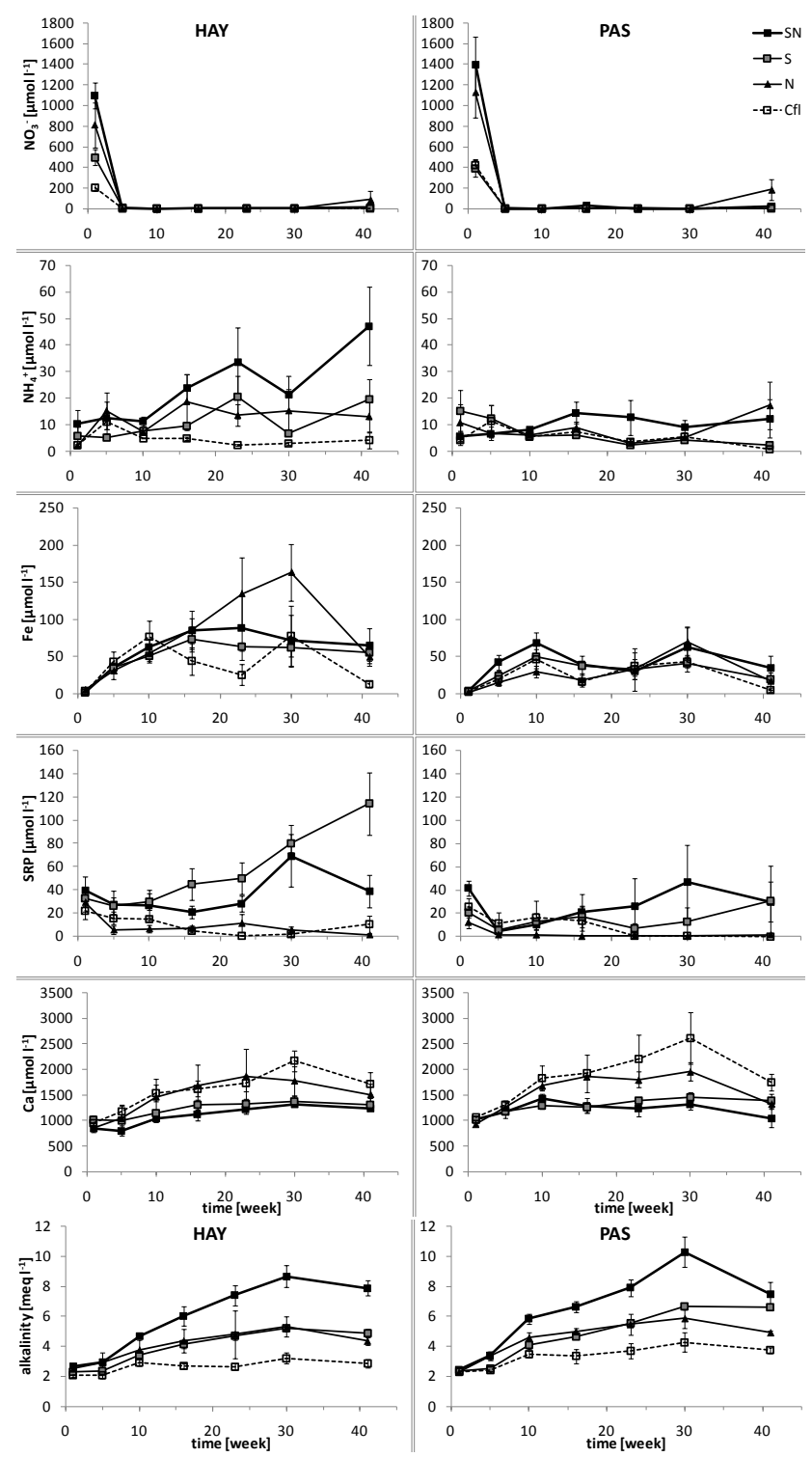

Fig. 3. Changes in concentrations of selected elements in surface water - means $\pm \operatorname{SEM}(n=4)$.

\subsection{Vegetation response}

Inundation of sods resulted in a significant decline of the vegetation in terms of cover and number of the species in each functional group over time (Table 6a). Cover of the plants decreased by $21 \%$ in HAY and $4.8 \%$ in PAS after 41 weeks in flooded sods. At this time, plants covered almost the whole surface of non flooded sods $(\mathrm{Cm})$ from both meadows $(98$ and $93 \%$, Fig. 4). Cm sods had a high number of individual small plants for herbs, grasses $(\mathrm{G} \times \mathrm{I})$ and Carex species, with a relatively low biomass. Flooding changed this composition, leading to a drastic reduction of herbs and relatively stronger development of grasses and Carex species $(t \times \mathrm{G} \times \mathrm{I})$. Moreover, species composition differed significantly $(\mathrm{G} \times \mathrm{L})$ 
Table 6. Statistical results for time $(t)$ effects and their interactions with land use (L) for (a) flooded versus non-flooded soils (I), and (b) interactions time with land use (L), water quality (W) and group of vegetation (G) for flooded soils only examined by means of GLM5.

\begin{tabular}{lcllclc}
\hline (a) & Vegetation cover & Biodiversity & (b) & Vegetation cover & Biodiversity & Algae cover \\
\hline$t$ & $\mathbf{1 0 . 7 0}^{* * *}$ & $\mathbf{3 8 . 8 8}^{* * *}$ & $t$ & $\mathbf{2 4 . 2 2}^{* * *}$ & $\mathbf{2 9 . 9 3}^{* * *}$ & $\mathbf{2 6 . 6 7 ^ { * * * * }}$ \\
$t \times \mathrm{G}$ & - & $\mathbf{1 5 . 2 8}^{* * *}$ & $t \times \mathrm{G}$ & - & $\mathbf{1 4 . 3 0}^{* * *}$ & - \\
$t \times \mathrm{L}$ & $0.72^{\mathrm{NS}}$ & $0.70^{\mathrm{NS}}$ & $t \times \mathrm{L}$ & $2.74^{\mathrm{NS}}$ & $1.83^{\mathrm{NS}}$ & $0.78^{\mathrm{NS}}$ \\
$t \times \mathrm{I}$ & $\mathbf{6 . 4 9}^{* *}$ & $\mathbf{4 1 . 8 9}^{* * *}$ & $t \times \mathrm{W}$ & $1.13^{\mathrm{NS}}$ & $0.95^{\mathrm{NS}}$ & $\mathbf{2 . 5 1}^{* *}$ \\
$t \times \mathrm{G} \times \mathrm{L}$ & - & $1.27^{\mathrm{NS}}$ & $t \times \mathrm{G} \times \mathrm{L}$ & - & $0.67^{\mathrm{NS}}$ & - \\
$t \times \mathrm{G} \times \mathrm{I}$ & - & $\mathbf{1 6 . 3 7}^{* * *}$ & $t \times \mathrm{G} \times \mathrm{W}$ & - & $0.84^{\mathrm{NS}}$ & - \\
$t \times \mathrm{L} \times \mathrm{I}$ & $0.83^{\mathrm{NS}}$ & $0.39^{\mathrm{NS}}$ & $t \times \mathrm{L} \times \mathrm{W}$ & $0.44^{\mathrm{NS}}$ & $1.00^{\mathrm{NS}}$ & $1.26^{\mathrm{NS}}$ \\
$t \times \mathrm{G} \times \mathrm{L} \times \mathrm{I}$ & - & $0.90^{\mathrm{NS}}$ & $t \times \mathrm{G} \times \mathrm{L} \times \mathrm{W}$ & - & $\mathbf{1 . 5 8}^{*}$ & - \\
$\mathrm{G}$ & - & $\mathbf{6 8 8 . 7 1}^{* * *}$ & $\mathrm{G}$ & - & $\mathbf{5 . 1 4}^{* *}$ & - \\
$\mathrm{L}$ & $1.04^{\mathrm{NS}}$ & $\mathbf{1 1 . 1 5}^{* *}$ & $\mathrm{~L}$ & $\mathbf{5 . 6 0}^{*}$ & $\mathbf{6 . 5 2}^{*}$ & $\mathbf{1 7 . 4 5}^{* * *}$ \\
$\mathrm{I}$ & $\mathbf{5 3 . 5 0}^{* * *}$ & $\mathbf{7 2 . 7 5}^{* * *}$ & $\mathrm{~W}$ & $1.77^{\mathrm{NS}}$ & $1.56^{\mathrm{NS}}$ & $0.25^{\mathrm{NS}}$ \\
$\mathrm{G} \times \mathrm{L}$ & - & $\mathbf{6 . 5 8}^{* *}$ & $\mathrm{G} \times \mathrm{L}$ & - & $\mathbf{7 . 9 2}^{* *}$ & - \\
$\mathrm{G} \times \mathrm{I}$ & - & $\mathbf{4 5 . 7 2}^{* * *}$ & $\mathrm{G} \times \mathrm{W}$ & - & $1.50^{\mathrm{NS}}$ & - \\
$\mathrm{L} \times \mathrm{I}$ & $1.55^{\mathrm{NS}}$ & $1.84^{\mathrm{NS}}$ & $\mathrm{L} \times \mathrm{W}$ & $0.61^{\mathrm{NS}}$ & $1.23^{\mathrm{NS}}$ & $1.24^{\mathrm{NS}}$ \\
$\mathrm{G} \times \mathrm{L} \times \mathrm{I}$ & - & $2.39^{\mathrm{NS}}$ & $\mathrm{G} \times \mathrm{L} \times \mathrm{W}$ & - & $1.00^{\mathrm{NS}}$ & - \\
\hline
\end{tabular}

$t$ - time, $\mathrm{L}$ - land use, I - inundation, $\mathrm{G}$ - group of vegetation, $\mathrm{W}-$ water quality, - Not included in the model, $* * * p<0.001, * * p<0.01$, $* p<0.05$, NS not significant

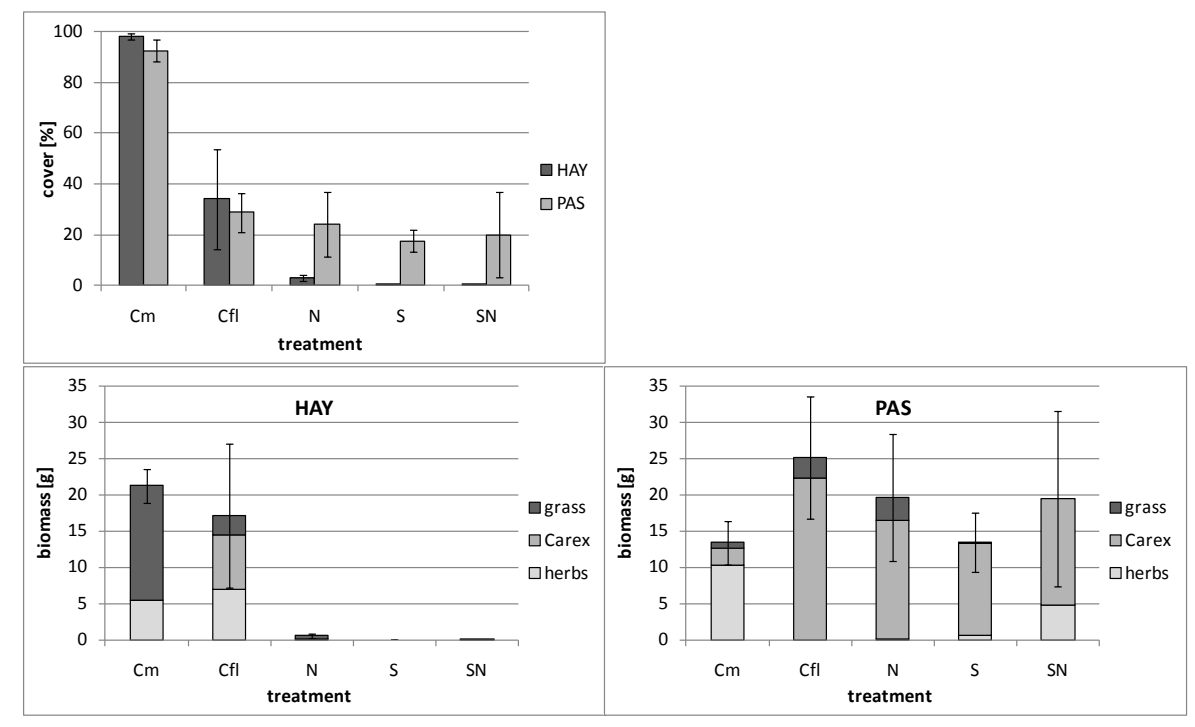

Fig. 4. Vegetation data (cover above and biomass of each group below) at the end of the inundation period (week 41) - means \pm SEM ( $n=4)$. Error bars of biomass represent SEM for the total biomass.

between meadows - HAY was dominated mainly by grasses and herbs with a very low number of individuals of Carex species, whilst PAS had much more individuals of herbs and Carex and a similar number of individuals of grasses compared to HAY. Observed changes in cover and species composition were not only time-related $(t \times \mathrm{I})$ but also depended on land use (higher for PAS, Table 6). We did not observe a significant role of water quality $(p=0.18$ and 0.21 for cover and biodiversity, Table 6b). There was, however, an initial stimulation of the vegetation growth in $\mathrm{N}$ treatments compared to $\mathrm{Cfl}$ control and a reduction by $\mathrm{S}$ and $\mathrm{SN}$, followed by a decline in all treatments (data not shown) resulting in the final situation presented in Fig. 4. Above-ground total biomass was clearly influenced by interacting effects of flooding and soil use (Table 7, Fig. 4). Flooded plants from HAY had lower biomass whilst those from the pasture were 
comparable to $\mathrm{Cm}$. Water composition had a significant effect on total biomass in HAY, where biomass was very low for the N, S and NS treatment. This adverse effect was not found for PAS.

Initially, vegetation cover was $41 \%$ for HAY and $39 \%$ for PAS ( $p=0.68$ ), composed of species from different functional groups, such as grasses and herbs. In addition Carex species were present, mainly on PAS (Table 2).

Herbs suffered the most due to flooding, and we noticed a strong decline of Cardamine spp. (PAS), Sanguisorba officinalis (HAY), Centaurea jacea, Filipendula ulmaria, Rumex acetosa, Trifolium repens, Veronica chamaedrys and Vicia spp. (HAY and PAS). For grasses only Anthoxanthum spp. (HAY) and Poa pratensis (PAS) declined. Other species were flooding-resistant, showing either survival or even stimulation of growth (Table 2).

Above-ground biomass of grasses was significantly lower (Table 7a) at the end of the study in comparison to summer (week 24) and it was lower in flooded sods in comparison to $\mathrm{Cm}$. This decline was stronger in HAY than PAS including non flooded controls. S and SN treatments had the strongest impact, followed by $\mathrm{N}$, leading to significantly lower biomass of grasses for both meadows (Table 7b). Biomass of Carex species, which are a target for ecosystem rehabilitation, was significantly higher in flooded sods (Table 7a), especially for PAS, without significant effect of water quality ( $p=0.25$, Table $7 \mathrm{~b}$ ). Carex grew well in all treatments on PAS whilst in HAY these species were present only in Cfl. Biomass of herbs declined due to inundation (Table 7a), but was not affected by water quality ( $p=0.97$, Table 7b). However, we noticed that biomass was higher in nutrient-rich treatments in PAS in comparison to $\mathrm{Cfl}(\mathrm{L} \times \mathrm{W})$ whilst HAY, in contrast, showed reversed tendency.

Inundation of sods led to development of algae up to a cover of $100 \%$ of the water surface (Table $6 \mathrm{~b}$ ). There was a significantly higher mean overall algae cover in HAY (49\%) than PAS (23\%). Development of algae did, however, not depend on water quality ( $p=0.86$, Table $6 \mathrm{~b})$.

The mean N:P ratio in plant tissue was $3.9 \mathrm{gg}^{-1}$ (HAY) and 2.2 (PAS) for non inundated plants (results not shown). Inundation led to significant changes of this ratio: in PAS it increased to 8.1 and in HAY to $5.4(p<0.05)$. The initial $\mathrm{P}: \mathrm{K}$ ratio $(\mathrm{Cm})$ was 0.16 for HAY and 0.22 for PAS ( $p=0.15$ ), changing to 0.19 and 0.11 after flooding. We did not observe an influence of water quality on both ratios.

\section{Discussion}

We showed that permanent inundation of floodplain sediments significantly influenced both soil biogeochemistry and vegetation development, but that the severity of these redoxrelated changes appeared to be strongly determined by the interactions between soil characteristics, as determined by land use, and water quality. This response is in contrast to our earlier findings on short-term flooding during summer, where flooding itself rather than water quality determined the biogeochemical response and the vegetation development (Banach et al., 2009b). The hydrological conditions tested in the present study relate to those in more or less pristine marshes dominated by sedges (Wassen et al., 2002; Kotowski et al., 2006).

\subsection{Effects of flooding on redox-related processes}

Permanent flooding led to strong changes in soil due to a switch from aerobic to anaerobic conditions. Subsequent alternative electron acceptors $\left(\mathrm{NO}_{3}^{-}, \mathrm{Mn}^{4+}, \mathrm{Fe}^{3+}\right.$ and $\mathrm{SO}_{4}^{2-}$ ) were reduced leading to the sequential decrease of $\mathrm{NO}_{3}^{-}$concentration, mobilization of $\mathrm{NH}_{4}^{+}, \mathrm{Mn}^{2+}, \mathrm{Fe}^{2+}$, and $\mathrm{SO}_{4}^{2-}$ reduction (Figs. 2-3; Gliński and Stępniewski, 1985; Laanbroek, 1990). These redox-related processes were the main cause of $P$ eutrophication and accumulation of reduced compounds, which may both pose a threat for the biodiversity of the developing vegetation (Lamers et al., 1998; Smolders et al., 2006; Loeb et al., 2008b; Banach et al., 2009b) and are strongly related to the season (Antheunisse and Verhoeven, 2008; Beumer et al., 2008; Loeb et al., 2008b). As the observed eutrophication was not caused by external $P$ input (Table 3), the elevated levels of SRP must have resulted from internal mobilization of accumulated P (so-called internal eutrophication, Roelofs, 1991; Smolders et al., 2006; Banach et al., 2009b). There were two key factors involved in this process: soil characteristics and water pollution with $\mathrm{SO}_{4}^{2-}$. The more fertilized HAY soil had higher Olsen P levels (Table 1) than PAS which could be responsible for differences between both tested soils (Fig. 2, Table 5). There are two possible sources of $\mathrm{P}$ in the soil: inorganically-bound and organically-bound $\mathrm{P}$ fractions. As an inorganic source, Fe-bound P is most of importance as SRP can be easily mobilized from this redox-sensitive fraction under anaerobic conditions due to Fe reduction (Patrick and Khalid, 1974; Caraco et al., 1989; Baldwin and Mitchell, 2000; Zak et al., 2004; Loeb et al., 2008a). Indeed, we measured increasing $\mathrm{Fe}^{2+}$ and SRP concentrations both in sediment pore water and surface water (Figs. 2-3). Levels of $\mathrm{Fe}^{2+}$ in surface water were much lower in comparison to those in sediment pore water due to oxidation of the surface water column (Loeb et al., 2007). The Fe-related $P$ mobilization appeared to be related to the low total soil Fe:P ratio (Table 1), which was around the threshold value of $12 \mathrm{~mol} \mathrm{~mol}^{-1}$ below which $\mathrm{P}$ is mobilized (Ramm and Scheps, 1997; Geurts et al., 2008). Another indicator, the $\mathrm{Fe}: \mathrm{PO}_{4}$ ratio in sediment pore water, correlated well with SRP in the surface water $\left(r_{s}=-0.76^{* *}, R^{2}=0.53\right)$ in a similar way as found by Smolders et al. (2001) and Geurts et al. (2008), with a threshold value of 3-4 mol mol${ }^{-1}$ below which SRP is strongly mobilized to the water layer, similar to the values found by others (Lehtoranta and Heiskanen, 2003; Zak et al., 2004). Moreover, $\mathrm{Fe}: \mathrm{PO}_{4}$ ratio differed 
Table 7. Effects of time ( $t$ ), land use (L) on biomass of each group of plants caused by (a) inundation (I) and (b) water quality (W) by means of univariate ANOVA. We compared data from both harvests. In addition differences between flooded treatments are presented for each group (c) - treatments with the same letter are not significantly different.

\begin{tabular}{lccclccc}
\hline (a) & Grass & Carex & Herbs & (b) & Grass & Carex & Herbs \\
\hline$t$ & $\mathbf{1 2 . 6 2}^{* *}$ & $0.04^{\mathrm{NS}}$ & $2.74^{\mathrm{NS}}$ & $t$ & $\mathbf{1 4 . 7 6}^{* * *}$ & $0.47^{\mathrm{NS}}$ & $\mathbf{4 . 9 6}^{*}$ \\
$\mathrm{~L}$ & $\mathbf{7 . 0 5}^{*}$ & $\mathbf{1 9 . 8 8}^{* * *}$ & $\mathbf{5 . 2 9}^{*}$ & $\mathrm{~L}$ & $0.07^{\mathrm{NS}}$ & $\mathbf{3 8 . 9 1}^{* * *}$ & $1.15^{\mathrm{NS}}$ \\
$\mathrm{I}$ & $\mathbf{1 8 . 8 3}^{* * *}$ & $\mathbf{5 . 3 1}^{*}$ & $\mathbf{3 5 . 2 2}^{* * *}$ & $\mathrm{~W}$ & $\mathbf{3 . 6 8}^{*}$ & $1.42^{\mathrm{NS}}$ & $0.08^{\mathrm{NS}}$ \\
$t \times \mathrm{L}$ & $0.74^{\mathrm{NS}}$ & $0.01^{\mathrm{NS}}$ & $0.68^{\mathrm{NS}}$ & $t \times \mathrm{L}$ & $0.83^{\mathrm{NS}}$ & $0.40^{\mathrm{NS}}$ & $0.56^{\mathrm{NS}}$ \\
$t \times \mathrm{I}$ & $0.01^{\mathrm{NS}}$ & $0.25^{\mathrm{NS}}$ & $0.18^{\mathrm{NS}}$ & $t \times \mathrm{W}$ & $0.57^{\mathrm{NS}}$ & $0.02^{\mathrm{NS}}$ & $0.10^{\mathrm{NS}}$ \\
$\mathrm{L} \times \mathrm{I}$ & $\mathbf{5 . 8 5}^{*}$ & $3.61^{\mathrm{NS}}$ & $1.70^{\mathrm{NS}}$ & $\mathrm{L} \times \mathrm{W}$ & $0.64^{\mathrm{NS}}$ & $0.60^{\mathrm{NS}}$ & $\mathbf{2 . 9 5}^{*}$ \\
$t \times \mathrm{L} \times \mathrm{I}$ & $2.84^{\mathrm{NS}}$ & $0.58^{\mathrm{NS}}$ & $0.02^{\mathrm{NS}}$ & $t \times \mathrm{L} \times \mathrm{W}$ & $1.01^{\mathrm{NS}}$ & $0.03^{\mathrm{NS}}$ & $0.11^{\mathrm{NS}}$ \\
\hline
\end{tabular}

Post hoc comparisons

(c)

\begin{tabular}{lcll} 
Cfl & A & A & A \\
$\mathrm{N}$ & $\mathrm{AB}$ & $\mathrm{A}$ & $\mathrm{A}$ \\
$\mathrm{S}$ & $\mathrm{B}$ & $\mathrm{A}$ & $\mathrm{A}$ \\
$\mathrm{SN}$ & $\mathrm{AB}$ & $\mathrm{A}$ & $\mathrm{A}$ \\
\hline
\end{tabular}

$t$ - time, $\mathrm{L}$ - land use, I - inundation, $\mathrm{W}$ - water quality, $* * * p<0.001, * * p<0.01, * p<0.05$, NS not significant

significantly between tested soils and treatments, PAS having significantly higher $(p<0.001)$ values than HAY resulting in lower $\mathrm{P}$ mobilization although $\mathrm{Fe}^{2+}$ levels of the sediment pore water were equally high (Table 4, Fig. 2).

Differences in SRP levels between both soils could additionally be explained by the role of $\mathrm{Ca}^{2+}$ in $\mathrm{P}$ binding as described by Boström et al. (1988). In our study we found significant differences in the concentrations of $\mathrm{Ca}^{2+}$ in sediment pore water (Table 5) and a negative correlation $\left(r_{s}=-0.49 * *\right)$ with SRP. As $\mathrm{Ca}^{2+}$ increased and SRP decreased in sediment pore water for PAS, it can be concluded that there may have been precipitation of SRP with $\mathrm{Ca}^{2+}$ and/or $\mathrm{CaCO}_{3}$.

\subsection{Role of water quality on redox processes}

Increased $\mathrm{SO}_{4}^{2-}$ concentration of the surface water led to significantly higher $\mathrm{P}$ mobilization interacting with soil quality, which did not occur during short-term (1 month) flooding (Banach et al., 2009b). The Fe: $\mathrm{PO}_{4}$ ratio in sediment pore water was lower for $\mathrm{S}$ and $\mathrm{SN}$ treatments (below the threshold) suggesting additional internal eutrophication due to $\mathrm{SO}_{4}^{2-}$ influx and its reduction. Produced $\mathrm{H}_{2} \mathrm{~S}$ apparently interacted with the Fe-P cycle (Golterman, 1995; Roden and Edmonds, 1997; Smolders et al., 2006; Zak et al., 2006) and stimulated $\mathrm{P}$ mobilization (especially in HAY). However, both soils were Fe-rich which can explain the low $\mathrm{H}_{2} \mathrm{~S}$ concentrations in sediment pore water. Although the $\mathrm{Fe}^{2+}$ concentration is high, a large part is sequestered as $\mathrm{FeS}_{\mathrm{x}}$ and not available for $\mathrm{P}$ binding, as indicated by the relatively low $(\mathrm{Fe}-$ $\mathrm{S})$ to $\mathrm{P}$ ratio of 6-7 (Table 1). In addition, $\mathrm{SO}_{4}^{2-}$ reduction is known to generate alkalinity, which may play a role in further nutrient mobilization (especially P) as it stimulates de- composition and mineralization (Smolders et al., 2006). This process is expected to be additionally important in this study as we recorded production of alkalinity and TIC, especially for S and SN treatments (Fig. 2, Tables 4, 5). Unexpectedly, the presence of high concentrations of $\mathrm{NO}_{3}^{-}$in the surface water did not prevent $\mathrm{P}$ mobilization, as is known to occur in fens related to blocking of $\mathrm{Fe}$ reduction by the presence of this more favourable electron acceptor (Lucassen et al., 2004). This can probably be explained by the fast depletion of nitrate due to the stagnant situation, even though nitrate was supplied to keep the water levels constant.

\subsection{Consequences for vegetation development}

Flooding itself is a stress factor for non-wetland vegetation as it drastically changes physiological functioning of plants, such as photosynthesis, respiration and internal transport of nutrients, due to oxygen deficiency and accumulation of reduced compounds (Chen et al., 2005; Banach et al., 2009a). Herbs, the most abundant plant group on the studied meadows were most sensitive to flooding as could be expected for this terrestrial species group lacking specific adaptations to flooding (Van Eck et al., 2004; Banach et al., 2009a); 8 out of 26 species disappeared. Carex species and some of the grass species in the control flooding treatment were tolerant to flooding, as could be expected from their specific traits including the ability to oxidize their rhizosphere.

The vegetation response to permanent flooding, however, appeared to be strongly influenced by the interactions between soil use and water quality. The long term vegetation development after years of hydrological changes may, however, diverge because of succession related to long-term 
competition between plants, dispersal of diaspores and herbivory, processes that could not be included in the present experiment. There were striking differences in vegetation development between both meadows (as related to land use, affecting a number of soil characteristics including those shown in Table 1), with a very strong decline of the vegetation for HAY and luxurious growth of Carex species for PAS in N, S, and SN treatments. This may partly be related to the strong eutrophication of HAY, leading to algal development in the water layer which hampered vegetation growth. In addition, the lower redox potential related to the sequential depletion of alternative electron acceptors (inducing more severe oxygen stress) and the higher concentration of potentially phytotoxic substances in sediment pore water as a result of higher decomposition rates, including $\mathrm{H}_{2} \mathrm{~S}$ (for S-treated), nitrite $\left(\mathrm{NO}_{2}^{-}\right.$, for $\mathrm{N}$-treated), $\mathrm{NH}_{4}^{+}$, and possibly also organic acids which may have influenced vegetation development (Roelofs, 1991; Armstrong et al., 1996; de Graaf et al., 1998; Lamers et al., 1998; Lucassen et al., 2003; Van den Berg et al., 2005; Koch et al., 2007). It was, however clear that land use, leading to the above-mentioned effects, was the main determinant for the development of target (Carex) vegetation for marshland creation, and that more eutrophic soils require surface water with low concentrations of both $\mathrm{SO}_{4}^{2-}$ and $\mathrm{NO}_{3}^{-}$. The observed development of the vegetation was in strong contrast to the effects of short term flooding (Banach et al., 2009b), where all treatments showed equal reduction in vegetation cover as a result of flooding. Nutrient availability may also directly influence vegetation development and, by competition, diversity. In our study we noticed that inundation led to higher availability of both $\mathrm{N}$, $\mathrm{K}$, and especially P. Based on nutrient ratios in plant tissue, the vegetation on both soils appeared to be N-limited only, as $\mathrm{N}: \mathrm{P}$ ratios were lower than $12-14 \mathrm{~g} \mathrm{~g}^{-1}$ (Koerselman and Meuleman, 1996; Güsewell et al., 2003; Olde Venterink et al., 2003). The increased availability of $P$ due to flooding did not decrease these ratios in plant tissue, which further supports this idea. Although the increased availability of $\mathrm{N}$ may have changed the vegetation composition, the negative indirect effects of eutrophication, as explained above, appeared to be far more important for vegetation development.

Plant tissue C:N ratios were 14.6 and 7.9 for HAY and PAS, respectively (results not shown). These values are far below the critical level of 30 (Scheffer et al., 2001), suggesting a relatively strong potential for the decomposition of organic material at both locations. The apparently higher rate of decomposition for HAY could be caused by differences in P availability (Verhoeven and Arts, 1992), as the C:P ratio was significantly lower $(p<0.05)$ for PAS $(52$ instead of 127 , results not shown). This stresses the fact that peat formation is not only related to the development of potentially peat forming (Carex) vegetation, but also to the actual decomposition rates of its litter, as determined by interacting effects of land use and water quality.

\section{Conclusions}

Our study showed that the effects of long-term inundation of meadows, as in projects aiming at the restoration of marshes along rivers to increase water storage capacity, are strongly determined by the interactions between land use (level of fertilization) and water quality. The actual effects on biogeochemistry and vegetation will, in addition, strongly depend on the actual flooding duration and frequency, the flooding season and the water level. We tested the creation of a permanently, shallowly flooded situation throughout the year, as this is one of the possible measures to combine the reduction of flooding risks for the population and the restoration of marshes along rivers. These results differ from those of short-term summer flooding (Banach et al., 2009b) where flooding itself had the most striking effects on plant ecophysiology and soil biogeochemistry, regardless water quality. As the rate of the different biogeochemical processes and the growth of plants are both significantly influenced by temperature, winter flooding will have much less effects (e.g. Beumer et al., 2008; Loeb et al., 2008b).

Our work emphasizes the important role of land use (level of fertilization). For heavily fertilized soils, desired vegetation development only seems possible if sulphate and nitrate levels in the surface water are low as in less polluted rivers (Lamers et al., 2006). This means that for intensively used agricultural areas, water quality seems to be even more important than for other areas, which is rather unexpected. Strikingly, development of sedge fens was possible for less fertilized soils even at higher sulphate and nitrate levels, although plant biodiversity was still relatively low (partly due the absence of plant dispersal in our experiment) and peat formation is less probable due to still high levels of nutrients, presumably leading to high decomposition rates. Especially if water quality of rivers is still unfavourable with respect to sulphate and nitrate, restoration measures should concentrate on those areas that do not show a history of heavy fertilization.

Acknowledgements. The authors would like to acknowledge G. van der Weerden for his assistance in the greenhouse, G. Bögemann for his help with the description of the vegetation, and R. Loeb for her help with sample analysis.

Edited by: K. Küsel

\section{References}

Antheunisse, A. M., Loeb, R., Lamers L. P. M., and Verhoeven, J. T. A.: Regional differences in nutrient limitation in floodplains of selected European rivers: Implications for rehabilitation of characteristic floodplain vegetation, River Res. Appl., 22, 10391055, 2006.

Antheunisse A. M. and Verhoeven J. T. A.: Short-term responses of soil nutrient dynamics and herbaceous riverine plant communities to summer inundation, Wetlands, 28, 232-244, 2008. 
Armstrong, J., Afreen-Zobayed, F., and Armstrong, W.: Phragmites die-back: sulphide and acetic acid induced bud and root death, lignifications, and blockages within aeration and vascular systems, New Phytol., 134, 601-614, 1996.

Baldwin, D. S. and Mitchell, A. M.: The effects of drying and reflooding on the sediment and soil nutrient dynamics of lowland river - floodplain systems: a synthesis, Regul. River, 16, 457467, 2000

Banach, K., Banach, A. M., Lamers, L. P. M., de Kroon, H., Bennicelli, R. P., Smits, A. J. M., and Visser, E. J. W.: Differences in flooding tolerance between species from two wetland habitats with contrasting hydrology: implications for vegetation development in future floodwater retention areas, Ann. Bot-London, 103, 341-351, 2009a.

Banach, A. M., Banach, K., Visser, E. J. W., Stępniewska, Z., Smits, A. J. M., Roelofs, J. G. M., Lamers, L. P. M.: Effects of summer flooding on floodplain biogeochemistry in Poland; implications for increased flooding frequency, Biogeochemistry, 92, 247-262, $2009 b$.

Beniston, M., Stephenson, D. B., Christensen, O. B., Ferro, C. A. T., Frei, C., Goyette, S., Halsnaes, K., Holt, T., Jylhä, K., Koffi, B., Palutikof, J., Schöll, R., Semmler, T., and Woth, K.: Future extreme events in European climate: an exploration of regional climate model projections, Climatic Change, 81, 71-95, 2007.

Beumer, V., van Wirdum, G., Beltmnan, B., Griffioen, J., Grootjans, A. P., and Verhoeven, J. T. A.: Geochemistry and flooding as determining factors of plant species composition in Dutch winter-flooded riverine grasslands, Sci. Total Environ., 402, 7081, 2008.

Blom, C. W. P. M., Bögemann, G. M., Laan, P., van der Sman, A. J. M., van de Steeg, H. M., and Voesenek, L. A. C. J.: Adaptations to flooding in plants from river areas, Aquat. Bot., 38, 29-47, 1990.

Boström, B., Andersen, J. M., Fleischer, S., and Jansson, M.: Exchange of phosphorus across the sediment-water interface, Hydrobiologia, 170, 229-244, 1988.

Bronstert, A.: Floods and climate change: Interactions and impacts, Risk Anal., 23(3), 545-557, 2003.

Caraco, N. F., Cole, J. J., and Likens, G. E.: Evidence for sulphatecontrolled phosphorous release from sediments of aquatic systems, Nature, 341, 316-318, 1989.

Chen, H., Qualls, R. G., and Blank, R. R.: Effect of soil flooding on photosynthesis, carbohydrate partitioning and nutrient uptake in the invasive exotic Lepidium latifolium, Aquat. Bot., 82, 250268,2005

Christensen, J. H. and Christensen, O. B.: Climate modelling: severe summertime flooding in Europe, Nature, 421, 805-806, 2003.

Colmer, T. D.: Long-distance transport of gases in plants: a perspective on internal aeration and radial oxygen loss from roots, Plant Cell Environ., 26, 17-36, 2003.

De Graaf, M. C. C., Bobbink, R., Roelofs, J. G. M., and Verbeek, P. J. M.: Differential effects of ammonium and nitrate on three heathland species, Plant Ecol., 135(2), 185-196, 1998.

Field, A.: Discovering Statistics using SPSS, edited by: Wright, D. B., SAGE Publications, London, UK, 430-431, 2005.

Geurts, J. J. M., Smolders, A. J. P., Verhoeven, J. T. A., Roelofs, J. G. M., and Lamers, L. P. M.: Sediment Fe:PO4 ratio as a diagnostic and prognostic tool for the restoration of macrophyte bio- diversity in fen waters, Freshwater Biol., 53, 2101-2116, 2008.

Geurts, J. J. M., Sarneel, J. M., Willers, B. J. C., Roelofs J. G. M., Verhoeven, J. T. A., and Lamers, L. P. M.: Interacting effects of sulphate pollution, sulphide toxicity and eutrophication on vegetation development in fens: a mesocosm experiment, Environ. Pollut., 157, 2072-2081, 2009.

Gliński J. and Stępniewski, W.: Soil Aeration and its Role for Plants, CRC Press Inc., Boca Raton, 229 pp., 1985.

Golterman, H. L.: The role of the ironhydroxide-phosphatesulphide system in the phosphate exchange between sediments and overlying water, Hydrobiologia, 297, 43-54, 1995.

Golterman, H. L.: Fractionation of sediment phosphate with chealating compounds: a simplification, and comparison with other methods, Hydrobiologia, 335, 87-95, 1996.

Güsewell, S., Koerselman, W., and Verhoeven, J. T. A.: Biomass $\mathrm{N}: \mathrm{P}$ ratios as indicators of nutrient limitation for plant populations in wetlands, Ecol. Appl., 13, 372-384, 2003.

Koch, M. S., Schopmeyer, S. A., Holmer, M., Madden, C. J., and Kyhn-Hansen, C.: Thalassia testudinum response to the interactive stressors hypersalinity, sulfide and hypoxia, Aquat. Bot., 87, 104-110, 2007.

Koerselman, W. and Meuleman, A. F. M.: The vegetation N:P ratio: a new tool to detect the nature of nutrient limitation, J. Appl Ecol., 33, 1441-1450, 1996.

Kotowski, W., Thorig, W., van Diggelen, R., Wassen, M.J.: Competition as a factor structuring species zonation in riparian fens a transplantation experiment, Appl. Veg. Sci., 9, 231-240, 2006.

Kundzewicz, Z. W., Ulbrich, U., Brücher, T., Graczyk, D., Krüger, A., Leckebusch, G. C., Menzel, L., Pińskwar, I., Radziejewski, M., and Szwed, M.: Summer floods in Central Europe - Climate change track?, Nat. Hazards, 36, 165-189, 2005.

Laanbroek, H. J.: Bacterial cycling of minerals that affect plant growth in waterlogged soils: a review, Aquat. Bot., 38, 109-125, 1990.

Lamers, L. P. M., Tomassen, H. B. M., and Roelofs, J. G. M.: Sulphate-induced eutrophication and phytotoxicity in freshwater wetlands, Environ. Sci. Technol., 32, 199-205, 1998.

Lamers, L. P. M., Dolle, G. E. T., van den Berg, S. T. G., van Delft, S. P. J., and Roelofs, J. G. M.: Differential responses of freshwater wetland soils to sulphate pollution, Biogeochemistry, 55, 87-102, 2001.

Lamers, L. P. M., Falla, S. J., Samborska, E. M., van Dulken, I. A. R., van Hengstum, G., and Roelofs, J. G. M.: Factors controlling the extent of eutrophication and toxicity in sulphate-polluted freshwater wetlands, Limnol. Oceanogr., 47, 585-593, 2002a.

Lamers, L. P. M., Smolders, A. J. P., and Roelofs, J. G. M.: The restoration fens in the Netherlands, Hydrobiologia, 478, 107130, 2002b.

Lamers, L. P. M., Loeb, R., Antheunisse, A. M., Miletto, M., Lucassen, E. C. H. E. T., Boxman, A. W., Smolders, A. J. P., and Roelofs, J. G. M.: Biogeochemical constraints on the ecological rehabilitation of wetland vegetation in river floodplains, Hydrobiologia, 565, 165-186, 2006.

Lehtoranta, J. and Heiskanen, A.: Dissolved iron: phosphate ratio as an indicator of phosphate release to oxic water of the inner and outer coastal Baltic Sea, Hydrobiologia, 492, 69-84, 2003.

Loeb, R., van Daalen, E., Lamers, L. P. M., Roelofs, J. G. M.: How soil characteristics and water quality influence the biogeochemical response to flooding in riverine wetlands, Biogeochemistry, 
85, 289-302, 2007.

Loeb, R., Lamers, L. P. M., Roelofs, J. G. M.: Prediction of phosphorus mobilisation in inundated floodplain soils, Environ. Pollut., 156, 325-331, 2008a.

Loeb, R., Lamers, L. P. M., Roelofs, J. G. M.: Effects of winter versus summer flooding and subsequent desiccation on soil chemistry in a riverine hay meadow, Geoderma, 145, 84-90, 2008b.

Lucassen, E. C. H. E. T., Bobbink, R., Smolders, A. J. P., van der Ven, P. J. M., Lamers, L. P. M., and Roelofs, J. G. M.: Interactive effects of low $\mathrm{pH}$ and high ammonium levels responsible for the decline of Cirsium dissectum (L.) Hill, Plant Ecol., 165, 45-52, 2003.

Lucassen, E. C. H. E. T., Smolders, A. J. P., van der Salm, A. L., and Roelofs, J. G. M.: High groundwater nitrate concentrations inhibit eutrophication of sulphate-rich freshwater wetlands, Biogeochemistry, 67, 249-267, 2004.

Milly, P. C. D., Wetherald, R. T., Dunne, K. A., and Delworth, T. L.: Increasing risk of great floods in a changing climate, Nature, 415, 514-517, 2002.

Mommer, L., de Kroon, H., Pierik, R., Bögemann, G. M., and Visser, E. J. W.: A functional comparison of acclimation to shade and submergence in two terrestrial plant species, New Phytol., 167(1), 197-206, 2005.

Mommer, L. and Visser, E. J. W.: Underwater photosynthesis in flooded terrestrial plants: a matter of leaf plasticity, Ann. BotLondon, 96, 581-589, 2005.

Olde Venterink, H. G. M., Wassen, M. J., Verkroost, A. W. M., and De Ruiter, P. C.: Species richness-productivity patterns differ between N-, P-, and K-limited wetlands, Ecology, 84, 2191-2199, 2003.

Olsen, S. R., Cole, C. V., Watanabe, F. S., and Dean, L. A.: Estimation of available phosphorous in soils by extraction with sodium bicarbonate, US Dep. of Agric., Circ. 939, Washington, DC, 1954.

Patrick, W. H. and Khalid, R. A.: Phosphate release and sorption by soils and sediments - effect of aerobic and anaerobic conditions, Science, 186, 53-55, 1974.

Pezeshki, S. R.: Wetland plant responses to soil flooding, Environ. Exp. Bot., 46, 299-312, 2001.

Portnoy, J. W.: Salt marsh diking and restoration: Biogeochemical implications of altered wetland hydrology, Environ. Manage., 24(1), 111-120, 1999.

Ramm, K. and Scheps, V.: Phosphorous balance of a polytrophic shallow lake with the consideration of phosphorous release, Hydrologia, 342, 43-53, 1997.

Roden, E. E. and Edmonds, J. W.: Phosphate mobilization in iron-rich anaerobic sediments: microbial Fe(III) oxide reduction versus iron-sulfide formation, Arch. Hydrobiol., 139, 347-378, 1997.

Roelofs, J. G. M.: Inlet of alkaline river water into peaty lowlands: effects on water quality and Stratiotes aloides L. Stands, Aquat. Bot., 39, 267-293, 1991.

Rooth, J. E. and Stevenson, J. C.: Sediment deposition patterns in Phragmites australis communities: Implications for coastal areas threatened by rising sea-level, Wetl. Ecol. Manag., 8, 173-183, 2000.

Scheffer, R. A., van Logtestijn, R. S. P., and Verhoeven, J. T. A.: Decomposition of Carex and Sphagnum litter in two mesotrophic fens differing in dominant plant species, Oikos, 92(1), 44-54,
2001.

Schipper, L. A. and McLeod, M.: Subsidence rates and carbon loss in peat soils following conversion to pasture in the Waikato Region, New Zealand, Soil Use Manage., 18, 91-93, 2002.

Schwertmann, U.: Differenzierung der Eisenoxide des Bodens durch photochemishe Extration mit saurer AmmoniumoxalatLoesung, J. Plant. Nutr. Soil Sc., 105, 194-202, 1964.

Smits, A. J. M., Nienhuis, P. H., and Leuven, R. S. E. W.: New Approaches to River Management, Backhuys Publishers, Leiden, 356 pp., 2000.

Smolders, A. J. P., Nijboer, R. C., Roelofs, J. G. M.: Prevention of sulphide accumulation and phosphate mobilization by the addition of iron(II)chloride to a reduced sediment: an enclosure experiment, Freshwater Biol., 34, 559-568, 1995.

Smolders, A. J. P., Lamers, L. P. M., Moonen, M., Zwaga, K., and Roelofs, J. G. M.: Controlling phosphate release from phosphate-enriched sediments by adding various iron compounds, Biogeochemistry, 54, 219-228, 2001.

Smolders, A. J. P., Lamers, L. P. M., Lucassen, E. C. H. E. T., van der Velde, G., and Roelofs, J. G. M.: Internal eutrophication: How it works and what to do about it - a review, Chem. Ecol., 22, 93-111, 2006.

Sperber, J. I.: Release of phosphate from soil minerals by hydrogen sulphide, Nature, 181(34), 934 pp., 1958.

Swarzenski, C. M., Doyle, T. W., Fry, B., and Hagis, T. G.: Biogeochemical response of organic-rich freshwater marshes in the Louisiana delta plain to chronic river water influx, Biogeochemistry, 90, 49-63, 2008.

Van den Berg, L. J. L., Dorland, E., Vergeer, P., Hart, M. A. C., Bobbink, R., Roelofs, J. G. M.: Decline of acid-sensitive plant species in heathland can be attributed to ammonium toxicity in combination with low pH, New Phytol., 166, 551-564, 2005.

Van Eck, W. H. J. M., van de Steeg, H. M., Blom, C. W. P. M., and de Kroon, H.: Is tolerance to summer flooding correlated with distribution patterns in river floodplains? A comparative study of 20 terrestrial grassland species, Oikos, 107, 393-405, 2004.

Van Eck, W. H. J. M., Lenssen, J. P. M., Rengelink, R. H. J., Blom, C. W. P. M., and de Kroon, H.: Water temperature instead of acclimation stage and oxygen concentration determines responses to winter floods, Aquat. Bot., 81, 253-264, 2005.

Van Gemerden, H.: The sulphide affinity of phototrophic bacteria in relation to the location of elemental sulphur, Arch. Mikrobiol., 139, 289-294, 1984.

Van Stokkom, H. T. C., Smits, A. J. M., and Leuven, R. S. E. W.: Flood defence in the Netherlands: a new era, a new approach, Water Int., 30, 76-87, 2005.

Verhoeven, J. T. A. and Arts, H. H. M.: Carex litter decomposition and nutrient release in mires with different water chemistry, Aquat. Bot., 43(4), 365-377, 1992.

Vervuren, P. J. A., Blom, C. W. P. M., and de Kroon, H.: Extreme flooding events on the Rhine and the survival and distribution of riparian plant species, J. Ecol., 91, 135-146, 2003.

Wassen, M. J., Peeters, W. H. M., and Olde Venterink, H.: Patterns in vegetation, hydrology, and nutrient availability in an undisturbed river floodplain in Poland, Plant Ecol., 165, 27-43, 2002.

Wösten, J. H. M., Ismail, A. B., and van Wijk, A. L. M.: Peat subsidence and its practical implications: case study in Malaysia, Geoderma, 78, 25-36, 1997.

Young, E. O., Ross, D. S.: Phosphate release from seasonally 
flooded soils: a laboratory microcosm study, J. Environ. Qual., 30, 91-101, 2001.

Zak, D., Gelbrecht, J., Steinberg, C. E. W.: Phosphorus retention at the redox interface of peatlands adjacent to surface waters in northeast Germany, Biogeochemistry, 70, 357-368, 2004.
Zak, D., Kleeberg, A., and Hupfer, M.: Sulphate-mediated phosphorous mobilization in riverine sediments at increasing sulphate concentration, River Spree, NE Germany, Biogeochemistry, 80, 109-119, 2006. 